\title{
Clinical Effects of L-Carnitine Supplementation on Physical Performance in Healthy Subjects, the Key to Success in Rehabilitation: A Systematic Review and Meta-Analysis from the Rehabilitation Point of View
}

\author{
Michele Vecchio ${ }^{1,2, *(\mathbb{D})}$, Rita Chiaramonte ${ }^{1, *} \mathbb{D}$, Gianluca Testa ${ }^{3}$ (D) and Vito Pavone $^{3}$ \\ 1 Department of Biomedical and Biotechnological Sciences, Section of Pharmacology, University of Catania, \\ 95123 Catania, Italy \\ 2 Rehabilitation Unit, "AOU Policlinico Vittorio Emanuele", 95123 Catania, Italy \\ 3 Department of General Surgery and Medical Surgical Specialties, Section of Orthopaedics and Traumatology, \\ University Hospital Policlinico “Rodolico-San Marco", University of Catania, 95123 Catania, Italy; \\ gianluca.testa@unict.it (G.T.); vpavone@unict.it (V.P.) \\ * Correspondence: michele.vecchio@unict.it (M.V.); ritachiaramd@gmail.com (R.C.); \\ Tel.: +39-095-378-27-03 (M.V.); Fax: +39-095-731-53-84 (R.C.)
}

\section{check for} updates

Citation: Vecchio, M.; Chiaramonte, R.; Testa, G.; Pavone, V. Clinical Effects of L-Carnitine Supplementation on Physical Performance in Healthy Subjects, the Key to Success in Rehabilitation: A Systematic Review and Meta-Analysis from the Rehabilitation Point of View. J. Funct. Morphol. Kinesiol. 2021, 6, 93. https:// doi.org/10.3390/jfmk6040093

Academic Editor: Walter Herzog

Received: 21 April 2021

Accepted: 31 October 2021

Published: 4 November 2021

Publisher's Note: MDPI stays neutral with regard to jurisdictional claims in published maps and institutional affiliations.

Copyright: (c) 2021 by the authors. Licensee MDPI, Basel, Switzerland. This article is an open access article distributed under the terms and conditions of the Creative Commons Attribution (CC BY) license (https:/ / creativecommons.org/licenses/by/ $4.0 /)$.

\begin{abstract}
L-carnitine supplementation improves body strength, sports endurance and exercise capacity, as well as delaying the onset of fatigue. The aim of this study was to identify the correct dosage of supplementation to obtain improvements in physical performance and evaluate the changes related to L-carnitine supplementation in specific metabolic parameters, such as serum lactate, $\mathrm{VO}_{2}$, serum total and free carnitine at rest and after physical activities, in healthy subjects. The search was conducted on PubMed, EMBASE, Cochrane Library, Scopus and Web of Science and identified 6404 articles with the keywords: "carnitine" AND "exercises" OR "rehabilitation" OR "physical functional performance" OR "physical activity" OR "sports" OR "health" OR "healthy". A total of 30 publications met the inclusion criteria and were included in the systematic review. The metaanalysis did not show any significant differences in serum lactate values at rest and after exercise in healthy subjects who took L-carnitine supplementation $(p>0.05)$. On the contrary, L-carnitine administration significantly changed maximal oxygen consumption $\left(\mathrm{VO}_{2}\right)$ at rest $(p<0.005)$, serum free and total carnitine at rest and after exercise $(p<0.001)$. The dosage of supplementation that obtained a significant change in serum total carnitine was $2 \mathrm{~g} / \mathrm{dL}$ for 4 weeks at rest, $1 \mathrm{~g} / \mathrm{dL}$ for 3 weeks after exercise, and in serum free carnitine was $2 \mathrm{~g} / \mathrm{dL}$ for 3 weeks and $2 \mathrm{~g} / \mathrm{dL}$ for 4 weeks at rest. Based on our study, serum total and free carnitine at rest and after exercise, and $\mathrm{VO}_{2}$ at rest could be used to clinically follow individuals during physical activity and rehabilitation programs. Moreover, the supplementation should have a correct dosage to have maximum effect. Other robust trials are needed to find the best dosage to obtain positive results in metabolic parameters and in physical performance.
\end{abstract}

Keywords: carnitine; rehabilitation; physical activity

\section{Introduction}

L-carnitine (L 3-hydroxy-4-N-trimethyl amino-butyric acid) plays an essential role in enhancing endurance and recovery from fatigue [1].

The beneficial effects of both acute and chronic L-carnitine supplementation in several pathologic conditions are well described, such as infectious diseases (such as the Human immunodeficiency virus HIV), hemodialysis, cancer cachexia and dystonia [2-6]. Its intake has beneficial effects on healthy subjects, too. In the elderly, it reduces fatigue sensation and improves physical, mental and cognitive function as well as reducing fatigue [7]. In athletes, it facilitates the recovery process and increases blood flow and oxygen supply to 
muscle tissue [8]. In addition, it alleviates muscle injury and reduces markers of cellular damage, decreasing free radical formation [8].

The aim of the meta-analysis was to identify the correct dosage of supplementation to obtain improvements in physical performance and to investigate the changes related to L-carnitine supplementation in specific metabolic parameters, such as blood lactate, $\mathrm{VO}_{2}$, serum total and free carnitine at rest and after physical activity in healthy subjects.

\section{Methods}

\subsection{Search Strategy}

The search was performed on the following medical electronic databases: PubMed, EMBASE, Cochrane Library, Scopus and Web of Science. The reference list of the related articles was also used to search for other eligible papers. The search strategy was conducted from December 2019 to January 2021 with the following terms and keywords: "carnitine" AND "exercises" OR "rehabilitation" OR "physical functional performance" OR "exercises" OR "sport" OR "health" OR "healthy".

The search identified 6404 articles from 1976 to 2020. The reviewers analyzed 104 full texts. The eligibility for study inclusion was assessed independently. There were 30 publications that met the criteria and were included in the study (Table 1). The systematic review included 15 articles used for the meta-analysis. Data extraction included authors, year, sample characteristics, comparison and control groups, physical performance or rehabilitation outcomes, periodic assessments and follow-up, and outcomes identified after supplementation. After the removal of duplicates $(n=1675)$, several articles $(n=4637)$ were excluded because they were irrelevant on the basis of title and abstract or were irrelevant to the research question. A further 74 articles were excluded for other reasons: use of L-carnitine in several disorders and not in healthy subjects $(n=24)$, no supplementation of L-carnitine (endogenous carnitine) $(n=13)$, descriptive articles about the use of supplementation without quantitative measures (no concentration, dosage and duration of administration) $(n=11)$, not written in English $(n=4)$, contemporary administration of L-carnitine and other nutrients $(n=4)$, use of different kinds of L-carnitine not equivalent to L-carnitine $(n=18)$ (Figure 1$)$. 


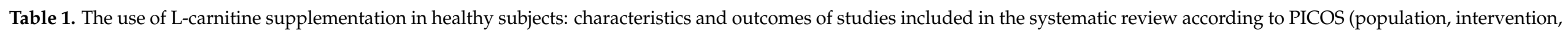
comparison, outcome and study design) criteria for the inclusion of studies.

\begin{tabular}{|c|c|c|c|c|c|}
\hline Authors, yr & $\begin{array}{c}\text { Study } \\
\text { Design; } \\
\text { Evidence Levels }\end{array}$ & $\begin{array}{l}\text { Population, } \\
\text { Y }\end{array}$ & Comparison Samples & $\begin{array}{l}\text { Intervention: L-Carnitine } \\
\text { Dosage }\end{array}$ & Outcomes \\
\hline Marconi 1985 & $\begin{array}{c}\text { RT; } \\
\text { Level } 2\end{array}$ & $\begin{array}{c}6 \text { competitive walkers m } \\
25.3 \mathrm{y}\end{array}$ & $\begin{array}{l}\text { A: Before supplementation } \\
\text { B: After supplementation }\end{array}$ & $4 \mathrm{~g} / \mathrm{d}, 2 \mathrm{w}$ & $\begin{array}{l}\text { Increased serum L-carnitine, no change in } \\
\text { blood lactate concentrations and } \mathrm{R} \text { at fixed } \\
\text { workload. The } 6 \% \text { increase in } \mathrm{VO}_{2} \text { was not } \\
\text { significantly related to carnitine intake. }\end{array}$ \\
\hline Cooper 1986 & $\begin{array}{c}\text { CT; } \\
\text { Level } 1\end{array}$ & $\begin{array}{l}10 \text { marathon runners } \mathrm{m} \\
19-25 \mathrm{y}\end{array}$ & $\begin{array}{l}\text { A: Before supplementation } \\
\text { B: After supplementation }\end{array}$ & $4 \mathrm{~g} / \mathrm{d}, 10 \mathrm{~d}$ & $\begin{array}{l}\text { L-carnitine supplementation increased the } \\
\text { tissue content of oxidized glutathione. }\end{array}$ \\
\hline Drăgan 1987 & $\begin{array}{c}\text { RT; } \\
\text { Level } 2\end{array}$ & 7 athletes & $\begin{array}{l}\text { A: Before supplementation } \\
\text { B: After supplementation }\end{array}$ & $1 \mathrm{~g} / \mathrm{d}$ for $6 \mathrm{w}+2 \mathrm{~g} / \mathrm{d}$ for $10 \mathrm{~d}$ & $\begin{array}{l}\text { Carnitine group showed better obtained } \\
\text { higher performances. }\end{array}$ \\
\hline Greig 1987 & $\begin{array}{c}\text { CT; } \\
\text { Level } 1\end{array}$ & $\begin{array}{c}19 \text { healthy subjects, } 7 \\
\mathrm{~m} / 12 \mathrm{f} \\
27.1 \pm 4.6 \mathrm{y}\end{array}$ & $\begin{array}{l}\text { A: } 9 \mathrm{~s}, 3 \mathrm{~m}, 6 \mathrm{f} \\
\text { B: } 10 \mathrm{~s}, 4 \mathrm{~m}, 6 \mathrm{f}\end{array}$ & $\begin{array}{l}\text { A: } 2 \mathrm{~g} / \mathrm{d}, 2 \mathrm{w} \\
\mathrm{B}: 2 \mathrm{~g} / \mathrm{d}, 4 \mathrm{w}\end{array}$ & $\begin{array}{l}\text { No change in maximum oxygen uptake } \\
\qquad\left(\mathrm{VO}_{2}, \mathrm{R}\right) .\end{array}$ \\
\hline Drăgan 1988 & $\begin{array}{c}\text { RT; } \\
\text { Level } 2 \\
\end{array}$ & 110 healthy subjects & $\begin{array}{l}\text { A: Before supplementation } \\
\text { B: After supplementation }\end{array}$ & $1 \mathrm{~g} / \mathrm{d}$ for $3 \mathrm{w}$ & $\begin{array}{c}\text { Improved athletic performance, lower } \\
\text { lactic acid. }\end{array}$ \\
\hline $\begin{array}{c}\text { Oyono-Enguelle } \\
1988\end{array}$ & $\begin{array}{c}\text { RT; } \\
\text { Level } 2\end{array}$ & 10 exercising subjects & $\begin{array}{l}\text { A: Before supplementation } \\
\text { B: After supplementation }\end{array}$ & $2 \mathrm{~g} / \mathrm{d}, 4 \mathrm{w}$ & $\begin{array}{l}\text { After L-carnitine intake, the levels } \\
\text { returned to their initial values } 6-8 \mathrm{w} \text { after } \\
\text { cessation of the supply. }\end{array}$ \\
\hline Soop 1988 & $\begin{array}{c}\text { RT; } \\
\text { Level } 2\end{array}$ & $\begin{array}{l}7 \text { moderately trained } \\
\text { subjects } \\
19-31 \mathrm{y}\end{array}$ & $\begin{array}{l}\text { A: Before supplementation } \\
\text { B: After supplementation }\end{array}$ & $5 \mathrm{~g} / \mathrm{d}, 5 \mathrm{~d}$ & $\begin{array}{c}\text { No change in O2 uptake and arterial levels } \\
\text { and turnover of FFA after L-carnitine } \\
\text { supplementation. }\end{array}$ \\
\hline Gorostiaga 1989 & $\begin{array}{c}\text { RT; } \\
\text { Level } 2\end{array}$ & $\begin{array}{c}10 \text { trained athletes, } 9 \mathrm{~m} / 1 \\
\mathrm{f} \\
25.8 \pm 2.2 \mathrm{y}\end{array}$ & $\begin{array}{l}\text { A: Before supplementation } \\
\text { B: After supplementation }\end{array}$ & $2 \mathrm{~g} / \mathrm{d}, 4 \mathrm{w}$ & $\begin{array}{l}\text { Reduced R during submaximal exercise } \\
\text { after supplementation. Increased lipid use } \\
\text { by muscles during exercise. } \\
\text { Oxygen uptake, heart rate, blood glycerol } \\
\text { and resting plasma free fatty acid } \\
\text { concentrations presented a nonsignificant } \\
\text { trend. }\end{array}$ \\
\hline Siliprandi 1990 & $\begin{array}{c}\text { CT; } \\
\text { Level } 1\end{array}$ & $\begin{array}{l}10 \text { moderately trained } \\
\text { subjects } \\
23-30 y\end{array}$ & $\begin{array}{l}\text { A: Before supplementation } \\
\text { B: After supplementation }\end{array}$ & $2 \mathrm{~g} / \mathrm{d}, 2 \mathrm{~d}$ & $\begin{array}{l}\text { L-carnitine supplementation decreased } \\
\text { plasma lactate and pyruvate concentration. }\end{array}$ \\
\hline
\end{tabular}


Table 1. Cont.

\begin{tabular}{|c|c|c|c|c|c|}
\hline Authors, yr & $\begin{array}{c}\text { Study } \\
\text { Design; } \\
\text { Evidence Levels }\end{array}$ & $\begin{array}{l}\text { Population, } \\
\text { Y }\end{array}$ & Comparison Samples & $\begin{array}{l}\text { Intervention: L-Carnitine } \\
\text { Dosage }\end{array}$ & Outcomes \\
\hline Vecchiet 1990 & $\begin{array}{c}\text { CT; } \\
\text { Level } 1\end{array}$ & $\begin{array}{l}10 \text { moderately trained } \\
\text { subjects } \\
22-30 y\end{array}$ & $\begin{array}{l}\text { A: Before supplementation } \\
\text { B: After supplementation }\end{array}$ & $2 \mathrm{~g} / \mathrm{d}$, one single dosage & $\begin{array}{l}\text { Increased } \mathrm{VO}_{2} \text {, maximal oxygen uptake, } \\
\text { power output and reduced pulmonary } \\
\text { ventilation and plasma lactate after } \\
\text { L-carnitine supplementation. }\end{array}$ \\
\hline Wyss 1990 & $\begin{array}{c}\text { RT; } \\
\text { Level } 2\end{array}$ & $\begin{array}{l}7 \text { healthy subjects } \\
22.2 \pm 2.3 \mathrm{y}\end{array}$ & $\begin{array}{l}\text { A: Before supplementation } \\
\text { B: After supplementation }\end{array}$ & $3 \mathrm{~g}, 1 \mathrm{w}$ & $\begin{array}{l}\text { Decreased } \mathrm{R} \text {, and rate of carbohydrate } \\
\text { transformation during hypoxia after } \\
\text { L-carnitine supplementation. }\end{array}$ \\
\hline Arenas 1991 & $\begin{array}{c}\text { CT; } \\
\text { Level } 1\end{array}$ & $\begin{array}{l}24 \text { athletes } \\
19-27 \text { y }\end{array}$ & $\begin{array}{l}\text { A: } 13 \text { and } 11 \text { s placebo } \\
\text { B: } 11 \text { s sprinters L-carnitine } \\
\text { C: } 13 \text { long-distance runners }\end{array}$ & $1 \mathrm{~g} / \mathrm{d}, 24 \mathrm{w}$ & $\begin{array}{l}\text { The supplementation avoids the decrease } \\
\text { of total and free muscle carnitine due to } \\
\text { training in athletes. }\end{array}$ \\
\hline Huertas 1992 & $\begin{array}{c}\text { CT; } \\
\text { Level } 1\end{array}$ & 14 athletes & $\begin{array}{l}\text { A: Before supplementation } \\
\text { B: After supplementation }\end{array}$ & $2 \mathrm{~g} / \mathrm{d}, 4 \mathrm{w}$ & $\begin{array}{l}\text { Increase in respiratory-chain enzyme } \\
\text { activities in the muscle. }\end{array}$ \\
\hline Natali 1993 & $\begin{array}{c}\text { CT; } \\
\text { Level } 1\end{array}$ & $\begin{array}{c}20 \text { healthy subjects } \\
\text { A: } 29.5 \pm 1.7 \text { years } \\
\text { B: } 29 \pm 2 y\end{array}$ & $\begin{array}{l}\text { A: } 8 \text { healthy } m \\
\text { B: } 12 \text { healthy }\end{array}$ & $\begin{array}{c}\text { A: } 1 \mathrm{~g}+0.5 \mathrm{~g} / \mathrm{h} \text { iv } \\
\text { B: } 3 \mathrm{~g}, \text { iv. } 40^{\prime} \text { before exercise }\end{array}$ & $\begin{array}{l}\text { No changes during exercise with } \\
\text { L-carnitine intake, but increased fatty acid } \\
\text { oxidation during recovery. }\end{array}$ \\
\hline Arenas 1994 & $\begin{array}{c}\text { CT; } \\
\text { Level } 1\end{array}$ & $\begin{array}{c}16 \text { long-distance runners } \\
28.3 \pm 7.1\end{array}$ & $\begin{array}{l}\text { A: } 8 \mathrm{~s} \text { placebo } \\
\text { B: } 8 \mathrm{~s} \text { L-carnitine }\end{array}$ & $2 \mathrm{~g} / \mathrm{d}, 4 \mathrm{w}$ & $\begin{array}{c}\text { The supplementation increased pyruvate } \\
\text { dehydrogenase complex activities. }\end{array}$ \\
\hline Brass 1994 & $\begin{array}{c}\text { CT; } \\
\text { Level } 1\end{array}$ & $\begin{array}{l}14 \text { athletes } \\
23-40 y\end{array}$ & $\begin{array}{l}\text { A: Before supplementation } \\
\text { B: After supplementation }\end{array}$ & $185 \mu \mathrm{mol} / \mathrm{kg} / 1 \mathrm{~d}$ iv & $\begin{array}{l}\text { No effect on skeletal muscle carnitine } \\
\text { homeostasis during exercise: on } \mathrm{R} \text {, muscle } \\
\text { lactate accumulation, plasma lactate } \\
\text { concentration, muscle glycogen utilization, } \\
\text { plasma } p \text {-hydroxybutyrate concentration } \\
\text { after L-supplementation. }\end{array}$ \\
\hline Colombani 1996 & $\begin{array}{c}\text { CT; } \\
\text { Level } 1\end{array}$ & $\begin{array}{l}7 \text { m runners } \\
36 \pm 3 y\end{array}$ & $\begin{array}{l}\text { A: Before supplementation } \\
\text { B: After supplementation }\end{array}$ & $4 \mathrm{~g} / \mathrm{d}, 1 \mathrm{~d}$ & $\begin{array}{l}\text { No effect on performance, and no changes } \\
\text { in running time and in R after L-carnitine } \\
\text { supplementation. }\end{array}$ \\
\hline Giamberardino 1996 & $\begin{array}{c}\text { RT; } \\
\text { Level } 2\end{array}$ & $\begin{array}{l}6 \text { healthy untrained } \\
\text { subjects, } \\
26 \pm 3.8 \mathrm{y}\end{array}$ & $\begin{array}{l}\text { A: Before supplementation } \\
\text { B: After supplementation }\end{array}$ & $\mathrm{A}: 3 \mathrm{~g} / \mathrm{d}, 3 \mathrm{w}$ & Protective effect against pain and damage. \\
\hline
\end{tabular}


Table 1. Cont.

\begin{tabular}{|c|c|c|c|c|c|}
\hline Authors, yr & $\begin{array}{c}\text { Study } \\
\text { Design; } \\
\text { Evidence Levels }\end{array}$ & $\begin{array}{c}\text { Population, } \\
\text { Y }\end{array}$ & Comparison Samples & $\begin{array}{c}\text { Intervention: L-Carnitine } \\
\text { Dosage }\end{array}$ & Outcomes \\
\hline Swart 1997 & $\begin{array}{c}\text { RT; } \\
\text { Level } 2\end{array}$ & $\begin{array}{c}7 \text { marathon runners } \\
-\end{array}$ & $\begin{array}{l}\text { A: Before supplementation } \\
\text { B: After supplementation }\end{array}$ & $2 \mathrm{~g} / \mathrm{d}, 6 \mathrm{w}$ & $\begin{array}{l}\text { After L-carnitine supplementation: } \\
\text { increase of peak treadmill running speed } \\
\text { of } 5.68 \% \text {, average } \mathrm{VO}_{2} \text {, free carnitine } \\
\text { levels, decreased heart rate and respiratory } \\
\text { exchange ratio values. }\end{array}$ \\
\hline Nuesch 1999 & $\begin{array}{c}\text { RT; } \\
\text { Level } 2\end{array}$ & 9 athletes & $\begin{array}{l}\text { A: Before supplementation } \\
\text { B: After supplementation }\end{array}$ & $1 \mathrm{~g} / \mathrm{d}$ after treadmill & $\begin{array}{l}\text { In athletes without L-carnitine intake, } \\
\text { plasma free carnitine concentration } \\
\text { decreased significantly } 10 \text { min after } \\
\text { exercise compared with baseline. } \\
\text { In athletes with oral L-carnitine } \\
\text { supplementation, the elevated plasma } \\
\text { concentration of free carnitine at baseline } \\
\text { did not decrease after maximal exercise. }\end{array}$ \\
\hline Muller 2002 & $\begin{array}{c}\text { RT; } \\
\text { Level } 2\end{array}$ & $\begin{array}{c}10 \text { healthy untrained } \\
\text { subjects } 5 \mathrm{~m} / 5 \mathrm{f} \\
36.4 \pm 12.8 \mathrm{y}\end{array}$ & $\begin{array}{l}\text { A: Before supplementation } \\
\text { B: After supplementation }\end{array}$ & $3 \mathrm{~g} / \mathrm{d}, 10 \mathrm{~d}$ & $\begin{array}{c}\text { Significant increase in fatty acid oxidation, } \\
\text { muscle weight, total body water and } \\
\text { metabolic rate. }\end{array}$ \\
\hline Wachter 2002 & $\begin{array}{c}\text { RT; } \\
\text { Level } 2\end{array}$ & $\begin{array}{l}8 \text { healthy subjects } \\
23-25 y\end{array}$ & $\begin{array}{l}\text { A: Before supplementation } \\
\text { B: After supplementation }\end{array}$ & $4 \mathrm{~g} / \mathrm{d}, 12 \mathrm{w}$ & $\begin{array}{l}\text { Significant increase in physical } \\
\text { performance after L-carnitine } \\
\text { supplementation. }\end{array}$ \\
\hline Stuessi 2005 & $\begin{array}{c}\text { CT; } \\
\text { Level } 1\end{array}$ & $\begin{array}{l}12 \mathrm{~m} \text { athletes, } \\
25 \pm 3 \mathrm{y}\end{array}$ & $\begin{array}{l}\text { A: Before supplementation } \\
\text { B: After supplementation }\end{array}$ & $2 \mathrm{~g} / \mathrm{d}$, lump sum & $\begin{array}{l}\text { No enhanced performance in endurance } \\
\text { after L-carnitine supplementation. }\end{array}$ \\
\hline Malaguarnera 2007 & $\begin{array}{c}\text { CT; } \\
\text { Level } 1\end{array}$ & $\begin{array}{l}64 \text { healthy elderly } \\
\text { subjects } \\
\text { A: } 101 \pm 1.3 \mathrm{y} \\
\text { B: } 101 \pm 1.4 \mathrm{y}\end{array}$ & $\begin{array}{l}\text { A: } 32 \text { s L-carnitine } \\
\text { B: } 34 \text { s placebo }\end{array}$ & $2 \mathrm{~g} / \mathrm{d}, 24 \mathrm{w}$ & $\begin{array}{l}\text { Improvements in fat mass, muscle mass, } \\
\text { blood carnitine, acylcarnitine, physical } \\
\text { and mental fatigue. }\end{array}$ \\
\hline Chun 2011 & $\begin{array}{c}\text { RT; } \\
\text { Level } 2\end{array}$ & $\begin{array}{l}36 \mathrm{~m} \text { soccer players } \\
20.67 \pm 1.21 \mathrm{y}\end{array}$ & $\begin{array}{l}\text { A: } 6 \mathrm{~s}, 2 \mathrm{~g} \text { L-carnitine } \\
\text { B: } 6 \mathrm{~s}, 3 \mathrm{~g} \text { L-carnitine, } \\
\text { C: } 6 \mathrm{~s}, 4 \mathrm{~g} \text { L-carnitine, } \\
\text { D: } 6 \mathrm{~s}, 5 \mathrm{~g} \text { L-carnitine } \\
\text { E: } 6 \mathrm{~s}, 6 \mathrm{~g} \text { L-carnitine } \\
\text { F: } 6 \mathrm{~s} \text {, no intake }\end{array}$ & $2-6 \mathrm{~g} / \mathrm{d}, 4 \mathrm{w}$ & $\begin{array}{l}\text { L-carnitine can enhance endurance and } \\
\text { recovery from fatigue in athletes, increase } \\
\mathrm{VO}_{2} \text { and decrease lactate concentration }\end{array}$ \\
\hline
\end{tabular}


Table 1. Cont

\begin{tabular}{|c|c|c|c|c|c|}
\hline Authors, yr & $\begin{array}{c}\text { Study } \\
\text { Design; } \\
\text { Evidence Levels }\end{array}$ & $\begin{array}{l}\text { Population, } \\
\text { Y }\end{array}$ & Comparison Samples & $\begin{array}{c}\text { Intervention: L-Carnitine } \\
\text { Dosage }\end{array}$ & Outcomes \\
\hline Orer 2014 & $\begin{array}{c}\text { CT; } \\
\text { Level } 1\end{array}$ & $\begin{array}{l}26 \text { footballers } \\
18.4 \pm 0.5 \mathrm{y}\end{array}$ & $\begin{array}{l}\text { A: } 12 \text { athletes placebo } \\
\text { B: } 14 \text { athletes L-carnitine }\end{array}$ & $\begin{array}{l}\text { A; } 3 \mathrm{~g} / \mathrm{d}, 1 \mathrm{~d} \\
\mathrm{~B}: 4 \mathrm{~g} / \mathrm{d}, 1 \mathrm{~d}\end{array}$ & $\begin{array}{l}\text { Supplementation affected performance } \\
\text { positively in terms of running speed } \\
\text { corresponding to specific lactate } \\
\text { concentrations, lactic acid and Borg scale } \\
\text { responses corresponding to running } \\
\text { speeds. }\end{array}$ \\
\hline Parandak 2014 & $\begin{array}{c}\text { CT; } \\
\text { Level } 1\end{array}$ & $\begin{array}{l}21 \text { healthy subjects } \\
\text { A: } 22.2 \pm 1.1 \mathrm{y} \\
\text { B: } 22.0 \pm 1.0 \mathrm{y}\end{array}$ & $\begin{array}{l}\text { A: } 10 \text { L-carnitine } \\
\text { B: } 11 \text { placebo }\end{array}$ & $2 \mathrm{~g} / \mathrm{d}, 2 \mathrm{w}$ & $\begin{array}{l}\text { TAC increased significantly } 14 \text { days after } \\
\text { supplementation. Serum MDA-TBARS, } \\
\text { CK, TAC, LDH were significantly lower } 24 \\
\text { h after exercise. } \\
\text { The supplementation alleviated the effects } \\
\text { on lipid peroxidation and muscle damage } \\
\text { markers. }\end{array}$ \\
\hline Bradasawi 2016 & $\begin{array}{c}\text { CT; } \\
\text { Level } 1\end{array}$ & $\begin{array}{l}50 \text { healthy subjects } \\
\text { A: } 68.2 \pm 6.3 \mathrm{y} \\
\text { B: } 68.2 \pm 6.5 \mathrm{y}\end{array}$ & $\begin{array}{l}\text { A: } 26 \text { s L-carnitine } \\
\text { B: } 24 \text { s placebo }\end{array}$ & $1.5 \mathrm{~g} / \mathrm{d}, 10 \mathrm{w}$ & $\begin{array}{l}\text { No significant changes in free L-carnitine, } \\
\text { total L-carnitine, acyl L-carnitine blood } \\
\text { level and frailty biomarkers (IL-6, TNF- } \alpha \text {, } \\
\text { and IGF-1) between the placebo group and } \\
\text { carnitine group. }\end{array}$ \\
\hline Koozehchian 2018 & $\begin{array}{c}\text { CT; } \\
\text { Level } 1\end{array}$ & $\begin{array}{l}23 \text { trained subjects } \\
\text { A: } 24.5 \pm 1.5 y \\
\text { B: } 25.5 \pm 1.5 y\end{array}$ & $\begin{array}{l}\text { A: } 11 \text { s placebo } \\
\text { B: } 12 \text { s L-carnitine }\end{array}$ & $2 \mathrm{~g} / \mathrm{d}, 9 \mathrm{w}$ & $\begin{array}{c}\text { No significant influence on muscle mass } \\
\text { though upper/lower body strength } \\
\text { improved. }\end{array}$ \\
\hline Mor 2018 & $\begin{array}{c}\text { CT; } \\
\text { Level } 1\end{array}$ & $\begin{array}{c}16 \text { taekwondo players } \\
18-28 \text { y }\end{array}$ & $\begin{array}{l}\text { A: } 8 \mathrm{~s} \text { L-carnitine } \\
\text { B: } 8 \mathrm{~s} \text { placebo }\end{array}$ & $1 \mathrm{~g} / \mathrm{d}, 1 \mathrm{w}$ & Low body fat mass. \\
\hline
\end{tabular}

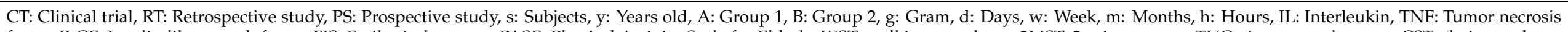

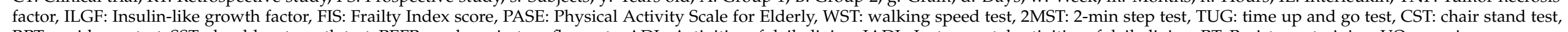

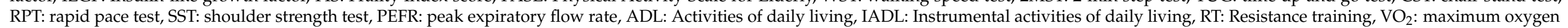

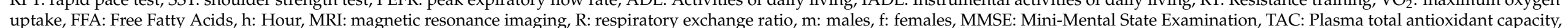

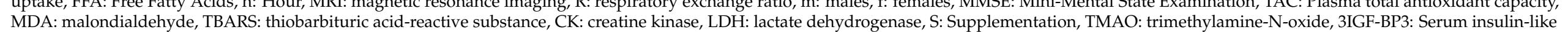
growth factor-binding protein, iv: Intravenously. 


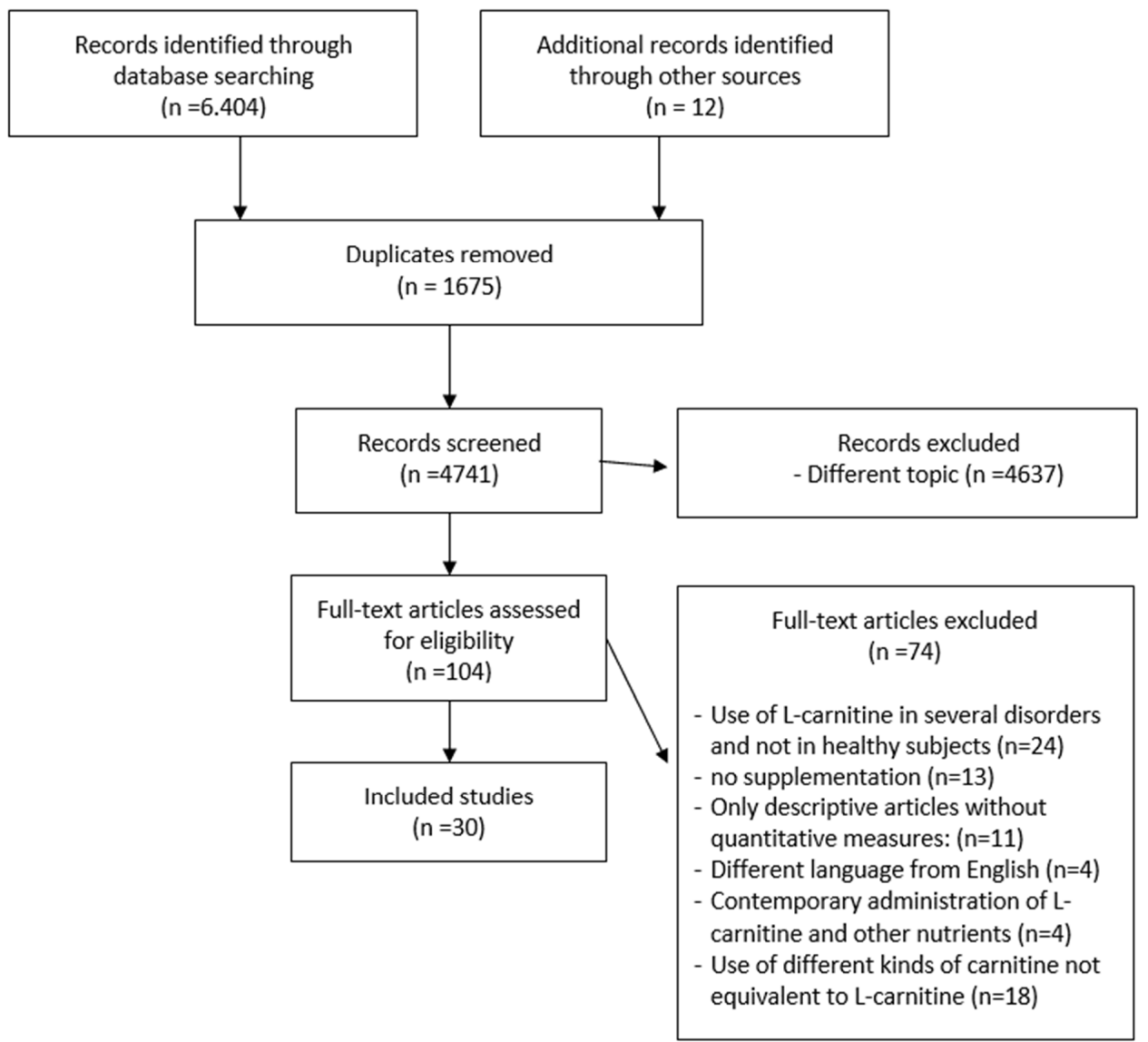

Figure 1. Flowchart of the process of initial literature search and extraction of studies meeting the inclusion criteria.

\subsection{Study Selection}

Studies were included in the review if they respected the following criteria: (a) design: randomized controlled trial (RCT), prospective and retrospective studies, only published data were permitted; (b) language: original article in English; (c) participants: healthy adults, including the elderly and athletes, who used dietary supplementation with Lcarnitine; (d) intervention: rehabilitative program and physical exercise; (e) comparison: no nutrient supplementation, or different dosage, or assessments at rest or after training; (f) outcomes: improvement of physical performance and changes in metabolic parameters.

Animal studies and papers without L-carnitine supplementation or papers with children or no healthy people as participants in the studies with L-carnitine supplementation were excluded. Any duplicates were also excluded.

The meta-analysis considered the studies with numeric values and quantitative data useful to quantify the outcomes and the effects of L-carnitine in healthy adults. These values were the maximal oxygen uptake $\left(\mathrm{VO}_{2}\right)$ and various blood parameters at rest and after exercise, such as plasma lactate, serum total and free carnitine.

This review is registered on PROSPERO: CRD42021229692.

\subsection{Data Collection Process, Data Extraction and Outcomes}

The titles and abstracts of studies retrieved using the search strategy and those from additional sources were screened independently by two authors to identify studies that potentially met the inclusion criteria outlined above.

Selected full texts were then reviewed and included in the systematic review and in the meta-analysis, following the Preferred Reporting Items for Systemic Reviews and Metaanalyses (PRISMA) statement [9], the Meta-analyses of Observational Studies (MOOSE) 
checklist [10] and the PICOS (population, intervention, comparison, outcome and study design) criteria [11] shown in Table 1: Participants were adults; Intervention was based on the supplementation of L-carnitine; Comparator was any comparator; Outcomes included clinical assessments and blood tests; and Study design included RCTs, and retrospective and prospective studies. Any disagreement over the eligibility of particular studies was resolved through discussion between the authors.

The main outcome was to show the effects of dietary L-carnitine intake in healthy subjects, adults, the elderly and athletes that could be useful to improve physical performance and obtain better results in rehabilitation. The secondary outcome was to define the metabolic changes induced by L-carnitine addition and the best dosage according to the current literature.

\subsection{Risk of Bias}

Two authors independently assessed the risk of bias of the included studies using the Cochrane risk of bias tool [12]. The assessments of risk of bias included random sequence generation, allocation concealment, blinding of participants, blinding of outcome assessment, incomplete outcome data, selective reporting and other biases. The adequacy of included studies as low, unclear, moderate or high risk for each study was analyzed by the authors (Table 2).

Table 2. Risk of bias summary for each included study.

\begin{tabular}{|c|c|c|c|c|c|c|c|c|}
\hline Study, Year & $\begin{array}{l}\text { Random } \\
\text { Sequence } \\
\text { Generation }\end{array}$ & $\begin{array}{c}\text { Allocation } \\
\text { Conceal- } \\
\text { ment }\end{array}$ & $\begin{array}{l}\text { Blinding } \\
\text { Participants }\end{array}$ & $\begin{array}{l}\text { Blinding of } \\
\text { Outcome } \\
\text { Assessment }\end{array}$ & $\underset{\text { Data }}{\text { Incomplete }}$ & $\begin{array}{l}\text { Selective } \\
\text { Reporting }\end{array}$ & Other Bias & Risk of Bias \\
\hline Arenas 1991 & + & + & + & + & + & + & + & Low risk \\
\hline Arenas 1994 & + & + & + & + & + & + & + & Low risk \\
\hline Bradasawi 2016 & + & + & + & + & + & + & + & Low risk \\
\hline Brass 1994 & + & + & + & + & + & + & + & Low risk \\
\hline Colombani 1996 & + & + & + & + & + & + & + & Low risk \\
\hline Chun 2011 & + & + & - & - & + & + & + & Low risk \\
\hline Cooper 1986 & - & - & - & - & + & + & - & High risk \\
\hline Dragan 1987 & + & + & + & + & + & + & + & Low risk \\
\hline Dragan 1988 & + & + & + & + & + & + & + & Low risk \\
\hline Giamberardino 1996 & + & + & + & + & + & + & + & Low risk \\
\hline Gorostiaga 1989 & - & - & + & + & + & + & + & Low risk \\
\hline Greig 1987 & + & + & + & + & + & + & + & Low risk \\
\hline Huertas 1992 & + & + & + & + & + & + & + & Low risk \\
\hline Koozehchian 2018 & + & + & + & + & + & + & + & Low risk \\
\hline Malaguarnera 2007 & + & + & + & + & + & + & + & Low risk \\
\hline Marconi 1985 & + & + & - & - & + & + & + & Low risk \\
\hline Mor 2018 & + & + & + & + & + & + & + & Low risk \\
\hline Muller 2002 & - & - & - & - & + & + & + & High risk \\
\hline Natali 1993 & + & + & - & - & + & + & + & Low risk \\
\hline Nuesch et al.1999 & - & - & - & - & + & + & + & High risk \\
\hline Orer 2014 & + & + & + & + & + & + & + & Low risk \\
\hline Oyono-Enguelle 1988 & - & - & - & - & + & + & + & High risk \\
\hline Parandak 2014 & + & + & + & + & + & + & + & Low risk \\
\hline Siliprandi 1990 & + & + & + & + & + & + & + & Low risk \\
\hline Soop 1988 & - & - & + & + & + & + & + & Low risk \\
\hline Stuessi 2005 & + & + & + & + & + & + & + & Low risk \\
\hline Swart 1997 & - & - & - & - & + & + & + & High risk \\
\hline Vecchiet 1990 & + & + & + & + & + & + & + & Low risk \\
\hline Wachter 2002 & - & - & - & - & + & + & + & High risk \\
\hline Wyss 1990 & - & - & + & + & + & + & + & High risk \\
\hline
\end{tabular}




\subsection{Quality of Outcomes}

The Grading of Recommendations Assessment, Development and Evaluation (GRADE) guidelines [13-17] for systematic reviews were used to evaluate the quality of the results. The rating of the quality of the study outcome was carried out to indicate the degree of certainty (high, moderate, low or very low) of the total effect estimates (Table 3).

Table 3. GRADE quality of evidence.

\begin{tabular}{|c|c|c|c|c|c|c|c|}
\hline \multicolumn{5}{|c|}{ Quality Assessment } & \multicolumn{2}{|c|}{ Summary of Findings } & \multirow{2}{*}{$\begin{array}{l}\text { Quality of } \\
\text { Evidence } \\
\text { GRADE }\end{array}$} \\
\hline $\mathrm{N}^{\circ}$ of studies & Limitations & Inconsistency & Indirectness & $\begin{array}{c}\text { Publication } \\
\text { bias }\end{array}$ & Characteristics of & IRR $(95 \%$ CI) & \\
\hline \multirow{3}{*}{30 studies } & \multirow{3}{*}{$\begin{array}{l}\text { No significant } \\
\text { limitations }\end{array}$} & \multirow{3}{*}{$\begin{array}{l}\text { No serious } \\
\text { inconsistency }\end{array}$} & \multirow{3}{*}{$\begin{array}{l}\text { No serious } \\
\text { indirectness }\end{array}$} & \multirow{3}{*}{ Unlikely } & $\begin{array}{l}\text { Population: Adults } \\
\text { Intervention: } \\
\text { L-carnitine intake } \\
\text { Comparison: }\end{array}$ & & \multirow{3}{*}{ Moderate-High } \\
\hline & & & & & 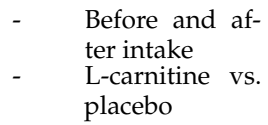 & $\begin{array}{l}\text { Fixed and } \\
\text { Random effects } \\
\text { model:Tables } 4-7\end{array}$ & \\
\hline & & & & & $\begin{array}{c}\text { Outcomes: } \\
\text { Improvement in } \\
\text { physical performance }\end{array}$ & & \\
\hline
\end{tabular}

\subsection{Meta-Analysis Calculations}

The Statistical Package for Social Sciences (SPSS, Version 18.0 for Windows; SPSS Inc., Chicago, IL, USA) was used for data analysis.

A synthesis of the findings from the included studies met the PICOS criteria. Summaries of intervention effects for each study were calculated with the standardized mean differences for continuous outcomes.

For the studies with the same type of intervention and comparator and with the same outcome measure, a random-effects meta-analysis with standardized mean differences for continuous outcomes was used, and 95\% confidence intervals and two-sided $p$ values for each outcome were calculated.

Heterogeneity was assessed using the inconsistency test $\left(\mathrm{I}^{2}\right)$. The $\mathrm{I}^{2}$ verified the impact of study heterogeneity on the results of the meta-analysis; an $\mathrm{I}^{2}$ value greater than $50 \%$ was indicative of substantial heterogeneity. An $\mathrm{I}^{2}$ value $<25 \%$ was indicative of a low risk of heterogeneity, a value between $25 \%$ and $50 \%$ was indicative of a moderate level of heterogeneity and $>50 \%$ was considered statistically significant between the included studies [18].

The sensitivity analysis was based on study quality. The stratified meta-analyses explored the heterogeneity according to: study quality; study populations; the logistics of intervention provision; and intervention content. The random-effect model estimated the combined effect sizes [19]. The quality of identified studies followed the methods of the Cochrane Collaboration [20], and publication bias was examined using funnel plots.

\section{Results}

\subsection{Variations of Experimental Conditions across the Studies}

The meta-analysis assessed the modifications in metabolic parameters after different dosages of L-carnitine and the differences at rest and after exercise.

The effectiveness of L-carnitine intake on levels of serum lactate is showed in Tables 4 and 5, $\mathrm{VO}_{2}$ in Table 6 and serum total and free carnitine in Tables 7 and 8. 
Table 4. Plasma lactate $(\mathrm{mmol} / \mathrm{L})$ at rest with and without L-carnitine supplementation.

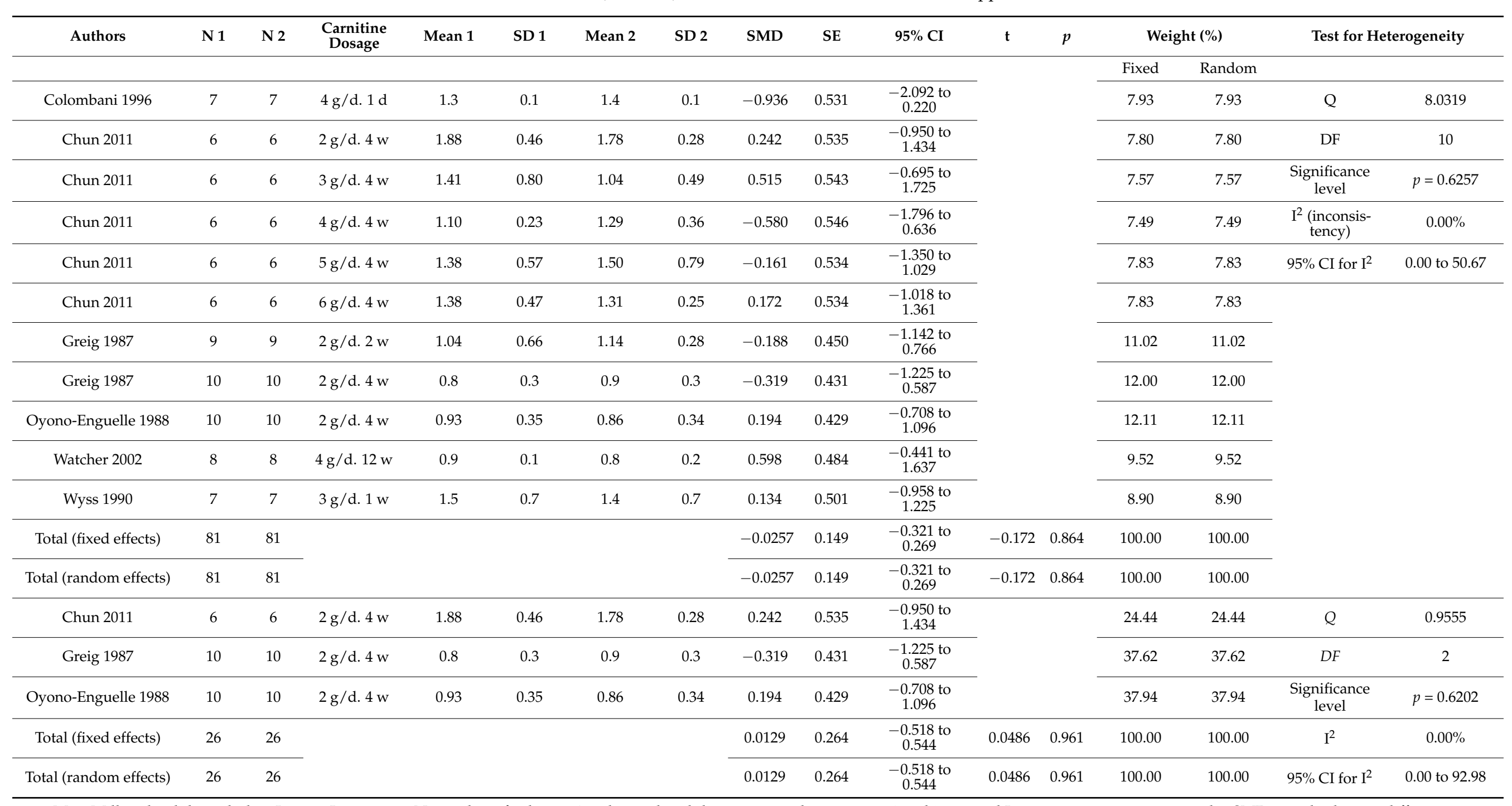

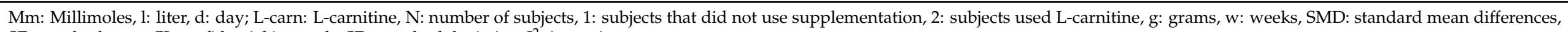
SE: standard error, CI: confidential intervals, SD: standard deviation, $\mathrm{I}^{2}$ : inconsistency. 
Table 5. Plasma lactate (mmol/L) after exercises with and without L-carnitine supplementation.

\begin{tabular}{|c|c|c|c|c|c|c|c|c|c|c|c|c|c|c|c|c|c|}
\hline Authors & N 1 & N 2 & Carn Dosage & Training & Mean 1 & SD 1 & Mean 2 & SD 2 & SMD & $\mathrm{SE}$ & $95 \% \mathrm{CI}$ & $\mathrm{t}$ & $p$ & \multicolumn{2}{|c|}{ Weight (\%) } & \multicolumn{2}{|c|}{$\begin{array}{c}\text { Test for } \\
\text { Heterogeneity }\end{array}$} \\
\hline & & & & & & & & & & & & & & Fixed & Random & & \\
\hline Colombani 1996 & 7 & 7 & $4 \mathrm{~g} / \mathrm{d} .1 \mathrm{~d}$ & $\begin{array}{l}20 \mathrm{~km} \text { of } \\
\text { running }\end{array}$ & 1.3 & 0.1 & 1.40 & 0.10 & -0.936 & 0.531 & $\begin{array}{c}-2.092 \text { to } \\
0.220 \\
\end{array}$ & & & 7.11 & 7.11 & $\mathrm{Q}$ & 10.937 \\
\hline Chun 2011 & 6 & 6 & $2 \mathrm{~g} / \mathrm{d} .4 \mathrm{w}$ & $\begin{array}{c}\text { After } \\
\text { exercise }\end{array}$ & 7.02 & 0.52 & 6.88 & 0.68 & 0.213 & 0.535 & $\begin{array}{l}-0.978 \text { to } \\
1.404\end{array}$ & & & 7.01 & 7.01 & DF & 11 \\
\hline Chun 2011 & 6 & 6 & $3 \mathrm{~g} / \mathrm{d} .4 \mathrm{w}$ & $\begin{array}{c}\text { After } \\
\text { exercise }\end{array}$ & 6.39 & 1.64 & 6.25 & 1.05 & 0.0938 & 0.533 & $\begin{array}{c}-1.094 \text { to } \\
1.282 \\
\end{array}$ & & & 7.05 & 7.05 & $\begin{array}{c}\text { Significance } \\
\text { level }\end{array}$ & $p=0.448$ \\
\hline Chun 2011 & 6 & 6 & $4 \mathrm{~g} / \mathrm{d} .4 \mathrm{w}$ & $\begin{array}{c}\text { After } \\
\text { exercise }\end{array}$ & 6.80 & 2.09 & 5.87 & 1.08 & 0.516 & 0.543 & $\begin{array}{c}-0.694 \text { to } \\
1.726\end{array}$ & & & 6.79 & 6.79 & $\begin{array}{l}\mathrm{I}^{2} \text { (inconsis- } \\
\text { tency) }\end{array}$ & $0.00 \%$ \\
\hline Chun 2011 & 6 & 6 & $5 \mathrm{~g} / \mathrm{d} .4 \mathrm{w}$ & $\begin{array}{c}\text { After } \\
\text { exercise }\end{array}$ & 6.96 & 1.87 & 6.31 & 1.56 & 0.348 & 0.537 & $\begin{array}{c}-0.849 \text { to } \\
1.546\end{array}$ & & & 6.93 & 6.93 & $95 \% \mathrm{CI}_{\text {for I }}{ }^{2}$ & 0.00 to 58.20 \\
\hline Chun 2011 & 6 & 6 & $6 \mathrm{~g} / \mathrm{d} .4 \mathrm{w}$ & $\begin{array}{c}\text { After } \\
\text { exercise }\end{array}$ & 6.80 & 0.98 & 6.09 & 1.16 & 0.610 & 0.547 & $\begin{array}{c}-0.609 \text { to } \\
1.829\end{array}$ & & & 6.69 & 6.69 & & \\
\hline Greig 1987 & 9 & 9 & $2 \mathrm{~g} / \mathrm{d} .2 \mathrm{w}$ & $\begin{array}{l}\text { After } 30^{\prime} \\
\text { of cycling }\end{array}$ & 11.7 & 2.1 & 10.10 & 2.60 & 0.645 & 0.462 & $\begin{array}{c}-0.334 \text { to } \\
1.623\end{array}$ & & & 9.40 & 9.40 & & \\
\hline Greig 1987 & 10 & 10 & $2 \mathrm{~g} / \mathrm{d} .4 \mathrm{w}$ & $\begin{array}{l}\text { After } 30^{\prime} \\
\text { of cycling }\end{array}$ & 11.8 & 4.4 & 10.70 & 3.00 & 0.280 & 0.431 & $\begin{array}{c}-0.625 \text { to } \\
1.184\end{array}$ & & & 10.80 & 10.80 & & \\
\hline Koozehchian2018 & 11 & 11 & $2 \mathrm{~g} / \mathrm{d} .9 \mathrm{w}$ & $\begin{array}{c}\text { Maximum } \\
\text { exercise }\end{array}$ & 5.73 & 1.14 & 4.60 & 0.97 & 1.027 & 0.438 & $\begin{array}{c}0.112 \text { to } \\
1.942 \\
\end{array}$ & & & 10.42 & 10.42 & & \\
\hline $\begin{array}{c}\text { Oyono-Enguelle } \\
1988 \\
\end{array}$ & 10 & 10 & $2 \mathrm{~g} / \mathrm{d} .4 \mathrm{w}$ & $\begin{array}{c}\text { After } 60^{\prime} \\
\text { cycling }\end{array}$ & 1.72 & 0.62 & 1.68 & 0.56 & 0.0648 & 0.428 & $\begin{array}{l}-0.835 \text { to } \\
0.965\end{array}$ & & & 10.91 & 10.91 & & \\
\hline Watcher 2002 & 8 & 8 & $4 \mathrm{~g} / \mathrm{d} .12 \mathrm{w}$ & $\begin{array}{c}\text { Power } \\
\text { exercise }\end{array}$ & 9.3 & 0.4 & 9.20 & 1.20 & 0.106 & 0.473 & $\begin{array}{c}-0.909 \text { to } \\
1.120\end{array}$ & & & 8.95 & 8.95 & & \\
\hline Wyss 1990 & 7 & 7 & $3 \mathrm{~g} / \mathrm{d} .1 \mathrm{w}$ & $\begin{array}{c}\text { Maximum } \\
\text { exercise }\end{array}$ & 8.1 & 1.7 & 8.80 & 3.30 & -0.250 & 0.503 & $\begin{array}{l}-1.344 \text { to } \\
0.845\end{array}$ & & & 7.93 & 7.93 & & \\
\hline Total (fixed effects) & 92 & 92 & & & & & & & 0.250 & 0.142 & $\begin{array}{l}-0.0297 \\
\text { to } 0.529\end{array}$ & 1.764 & 0.079 & 100.00 & 100.00 & & \\
\hline $\begin{array}{c}\text { Total (random } \\
\text { effects) }\end{array}$ & 92 & 92 & & & & & & & 0.250 & 0.142 & $\begin{array}{l}-0.0297 \\
\text { to } 0.529 \\
\end{array}$ & 1.764 & 0.079 & 100.00 & 100.00 & & \\
\hline \multirow[t]{2}{*}{ Authors } & $\mathrm{N} 1$ & N 2 & Carn. Dosage & Training & Mean 1 & SD 1 & Mean 2 & SD 2 & SMD & SE & $95 \% \mathrm{CI}$ & $\mathrm{t}$ & $p$ & \multicolumn{2}{|c|}{ Weight (\%) } & \multicolumn{2}{|c|}{ Test of heterogeneity } \\
\hline & & & & & & & & & & & & & & Fixed & Random & Q & 0.1252 \\
\hline Greig 1987 & 10 & 10 & $2 \mathrm{~g} / \mathrm{d} .4 \mathrm{w}$ & $\begin{array}{l}\text { After } 30^{\prime} \\
\text { of cycling }\end{array}$ & 11.8 & 4.4 & 10.70 & 3.00 & 0.280 & 0.431 & $\begin{array}{c}-0.625 \text { to } \\
1.184\end{array}$ & & & 49.75 & 49.75 & DF & 1 \\
\hline $\begin{array}{c}\text { Oyono-Enguelle } \\
1988 \\
\end{array}$ & 10 & 10 & $2 \mathrm{~g} / \mathrm{d} .4 \mathrm{w}$ & $\begin{array}{c}\text { After } 60^{\prime} \\
\text { cycling }\end{array}$ & 1.72 & 0.62 & 1.68 & 0.56 & 0.0648 & 0.428 & $\begin{array}{c}-0.835 \text { to } \\
0.965\end{array}$ & & & 50.25 & 50.25 & $\begin{array}{c}\text { Significance } \\
\text { level }\end{array}$ & $p=0.7235$ \\
\hline Total (fixed effects) & 20 & 20 & & & & & & & 0.172 & 0.304 & $\begin{array}{c}-0.443 \text { to } \\
0.787\end{array}$ & 0.566 & 0.575 & 100.00 & 100.00 & $\mathrm{I}^{2}$ & $0.00 \%$ \\
\hline $\begin{array}{l}\text { Total (random } \\
\text { effects) }\end{array}$ & 20 & 20 & & & & & & & 0.172 & 0.304 & $\begin{array}{c}-0.443 \text { to } \\
0.787 \\
\end{array}$ & 0.566 & 0.575 & 100.00 & 100.00 & $95 \% \mathrm{CI}_{\text {for } \mathrm{I}^{2}}$ & 0.00 to 0.00 \\
\hline
\end{tabular}

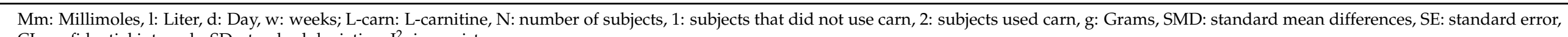

CI: confidential intervals, SD: standard deviation, $\mathrm{I}^{2}$ : inconsistency. 
Table 6. Maximal oxygen consumption $\mathrm{VO}_{2}(\mathrm{~mL} / \mathrm{min} / \mathrm{kg})$ at rest with and without L-carnitine supplementation and after exercise with and without L-carnitine supplementation.

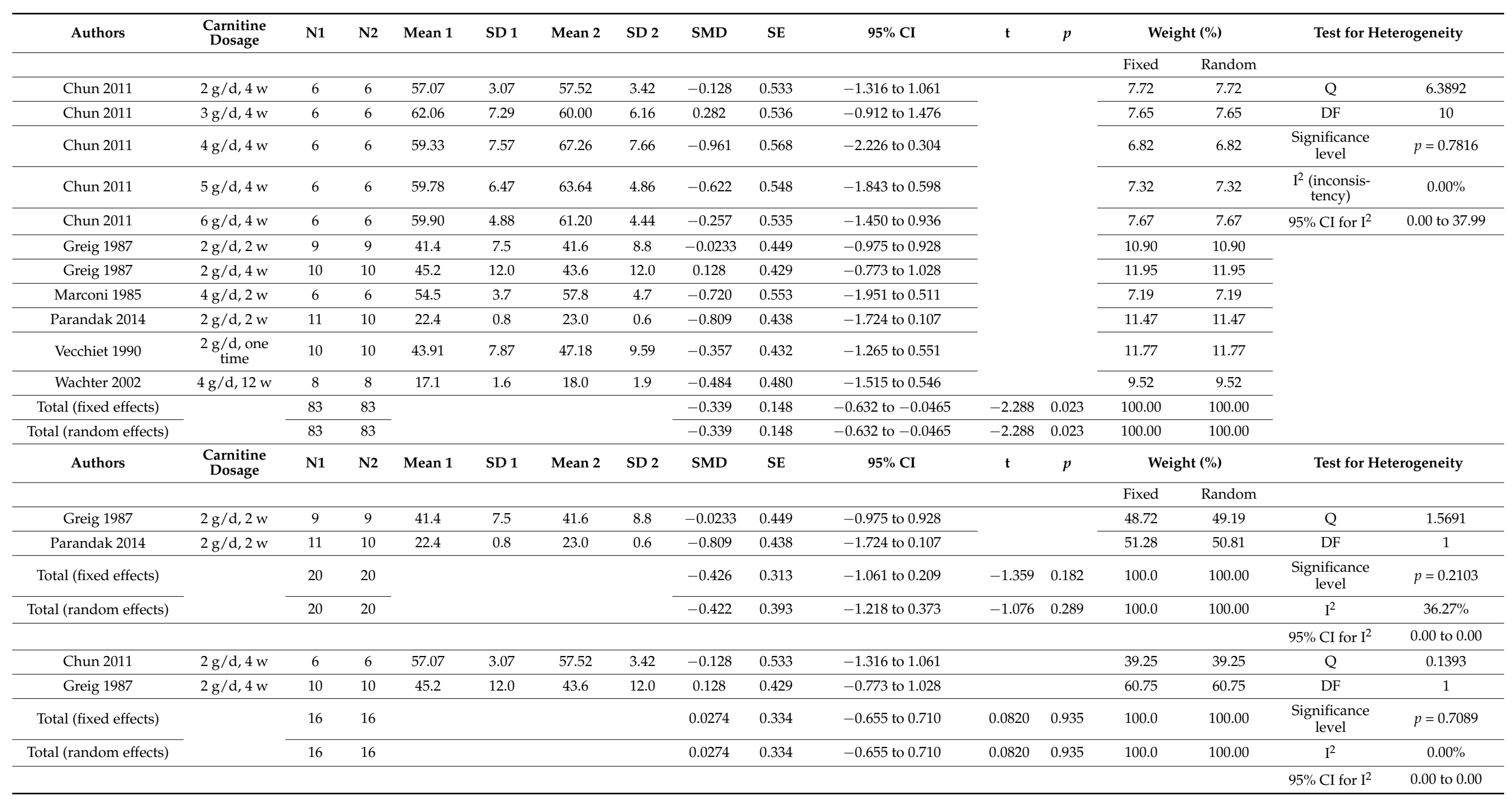

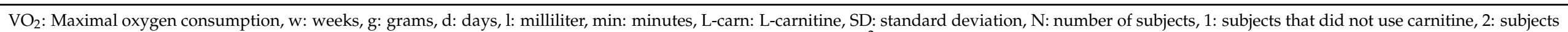
used carn, SMD: standard mean differences, SE: standard error, CI: confidential intervals, SD: standard deviation, $\mathrm{I}^{2}$ : inconsistency. 
Table 7. Serum total carnitine $(\mu \mathrm{mol} / \mathrm{L})$ at rest with and without L-carnitine supplementation and after exercise with and without L-carnitine supplementation.

\begin{tabular}{|c|c|c|c|c|c|c|c|c|c|c|c|c|c|c|c|c|c|}
\hline \multirow[t]{2}{*}{ Authors } & \multicolumn{2}{|c|}{ Carnitine Dosage } & \multirow[t]{2}{*}{ N1 } & \multirow[t]{2}{*}{ N2 } & \multirow[t]{2}{*}{ Mean 1} & \multirow[t]{2}{*}{ SD 1} & \multirow[t]{2}{*}{ Mean 2} & \multirow[t]{2}{*}{ SD 2} & \multirow[t]{2}{*}{ SMD } & \multirow[t]{2}{*}{ SE } & \multirow[t]{2}{*}{$95 \% \mathrm{CI}$} & \multirow[t]{2}{*}{$t$} & \multirow[t]{2}{*}{$p$} & \multicolumn{2}{|c|}{ Weight (\%) } & \multicolumn{2}{|c|}{ Test for Heterogeneity } \\
\hline & & & & & & & & & & & & & & Fixed & Random & & \\
\hline Arenas 1991 Runner & \multicolumn{2}{|c|}{$1 \mathrm{~g} / \mathrm{d}, 3 \mathrm{w}$} & 13 & 13 & 28 & 2 & 26.3 & 4.134 & 0.510 & 0.386 & -0.287 to 1.308 & & & 13.57 & 8.60 & $\mathrm{Q}$ & 62.7138 \\
\hline Arenas 1991 Sprinters & \multicolumn{2}{|c|}{$1 \mathrm{~g} / \mathrm{d}, 3 \mathrm{w}$} & 11 & 11 & 22.8 & 1.8 & 22.5 & 1.4 & 0.179 & 0.411 & -0.678 to 1.036 & & & 11.99 & 8.47 & DF & 12 \\
\hline Colombani 1996 & \multicolumn{2}{|c|}{$4 \mathrm{~g} / \mathrm{d}, 1 \mathrm{~d}$} & 7 & 7 & 51.4 & 2.8 & 57.9 & 1.6 & -2.668 & 0.710 & -4.215 to -1.120 & & & 4.02 & 6.73 & $\mathrm{I}^{2}$ (inconsistency) & $80.87 \%$ \\
\hline Gorostiaga 1989 & \multicolumn{2}{|c|}{$2 \mathrm{~g} / \mathrm{d}, 4 \mathrm{w}$} & 10 & 10 & 44.5 & 4.5 & 46.1 & 4.0 & -0.360 & 0.432 & -1.268 to 0.548 & & & 10.86 & 8.35 & $95 \% \mathrm{CI}$ for $\mathrm{I}^{2}$ & 68.26 to 88.47 \\
\hline Greig 1987 & \multicolumn{2}{|c|}{$2 \mathrm{~g} / \mathrm{d}, 2 \mathrm{w}$} & 9 & 9 & 55.3 & 7.6 & 78.9 & 16.3 & -1.767 & 0.537 & -2.905 to -0.629 & & & 7.03 & 7.75 & & \\
\hline Greig 1987 & \multicolumn{2}{|c|}{$2 \mathrm{~g} / \mathrm{d}, 4 \mathrm{w}$} & 10 & 10 & 41.3 & 8.4 & 56.0 & 8.2 & -1.696 & 0.505 & -2.758 to -0.634 & & & 7.94 & 7.94 & & \\
\hline Marconi 1985 & \multicolumn{2}{|c|}{$4 \mathrm{~g} / \mathrm{d}, 2 \mathrm{w}$} & 6 & 6 & 64.3 & 2.1 & 86.8 & 17.1 & -1.704 & 0.636 & -3.122 to -0.287 & & & 5.00 & 7.16 & & \\
\hline Muller 2002 & \multicolumn{2}{|c|}{$3 \mathrm{~g} / \mathrm{d}, 10 \mathrm{~d}$} & 10 & 10 & 47.07 & 6.82 & 59.86 & 9.52 & -1.479 & 0.488 & -2.504 to -0.454 & & & 8.51 & 8.04 & & \\
\hline Oyono-Eguelle 1988 & \multicolumn{2}{|c|}{$2 \mathrm{~g} / \mathrm{d}, 3 \mathrm{w}$} & 10 & 10 & 62.0 & 3.8 & 72.9 & 4.3 & -2.572 & 0.591 & -3.813 to -1.332 & & & 5.81 & 7.44 & & \\
\hline Oyono-Enguelle 1988 & \multicolumn{2}{|c|}{$2 \mathrm{~g} / \mathrm{d}, 4 \mathrm{w}$} & 10 & 10 & 62.0 & 3.8 & 79.8 & 3.8 & -4.486 & 0.829 & -6.227 to -2.745 & & & 2.95 & 6.05 & & \\
\hline Oyono-Enguelle 1988 & \multicolumn{2}{|c|}{$2 \mathrm{~g} / \mathrm{d}, 12 \mathrm{w}$} & 10 & 10 & 62.0 & 3.8 & 67.4 & 3.8 & -1.361 & 0.479 & -2.368 to -0.354 & & & 8.82 & 8.09 & & \\
\hline Swart 1997 & \multicolumn{2}{|c|}{$2 \mathrm{~g} / \mathrm{d}, 6 \mathrm{w}$} & 7 & 7 & 52.9 & 5.1 & 61.93 & 7.3 & -1.342 & 0.561 & -2.564 to -0.120 & & & 6.44 & 7.61 & & \\
\hline Total (fixed effects) & & & 120 & 120 & & & & & -1.085 & 0.142 & -1.366 to -0.805 & -7.624 & $<0.001$ & 100.00 & 100.00 & & \\
\hline Total (random effects) & & & 120 & 120 & & & & & -1.417 & 0.331 & -2.069 to -0.764 & -4.277 & $<0.001$ & 100.00 & 100.00 & & \\
\hline Authors & $\begin{array}{c}\text { Carn. } \\
\text { Dosage }\end{array}$ & Training & N1 & N2 & Mean 1 & SD 1 & Mean 2 & SD 2 & SMD & SE & $95 \% \mathrm{CI}$ & $t$ & $p$ & & (\%) & Test for Het & ogeneity \\
\hline Arenas 1991 Runner & $1 \mathrm{~g} / \mathrm{d}, 3$ & $\begin{array}{c}\text { After } \\
\text { exercise }\end{array}$ & 13 & 13 & 26.3 & 1.9 & 29.0 & 2.7 & -1.120 & 0.410 & -1.967 to -0.273 & & & 32.13 & 23.93 & $\mathrm{Q}$ & 26.2778 \\
\hline Arenas 1991 Sprinters & $1 \mathrm{~g} / \mathrm{d}, 3$ & $\begin{array}{c}\text { After } \\
\text { exercise }\end{array}$ & 11 & 11 & 21.6 & 1.5 & 24.3 & 1.4 & -1.790 & 0.491 & -2.814 to -0.766 & & & 22.44 & 23.00 & DF & 4 \\
\hline Colombani 1996 & $4 \mathrm{~g} / \mathrm{d}, 1 \mathrm{~d}$ & $\begin{array}{c}\text { After } \\
\text { running }\end{array}$ & 7 & 7 & 57.9 & 1.6 & 122.4 & 8.3 & -10.100 & 1.973 & $\begin{array}{c}-14.399 \text { to } \\
-5.801\end{array}$ & & & 1.39 & 7.79 & Significance level & 84.78 \\
\hline Gorostiaga 1989 & $2 \mathrm{~g} / \mathrm{d}, 4$ & $\begin{array}{c}\text { After } 40^{\prime} \\
\text { of } \\
\text { exercise }\end{array}$ & 10 & 10 & 47.4 & 5.9 & 49.1 & 4.9 & -0.300 & 0.431 & -1.205 to 0.605 & & & 29.14 & 23.70 & $\mathrm{I}^{2}$ (inconsistency) & $84.78 \%$ \\
\hline Marconi 1985 & $\underset{\mathrm{w}}{\mathrm{g} / \mathrm{d}, 2}$ & $\begin{array}{c}\text { After } 120^{\prime} \\
\text { of } \\
\text { treadmill }\end{array}$ & 6 & 6 & 86.8 & 17.1 & 109.8 & 13.4 & -1.382 & 0.603 & $\begin{array}{c}-2.725 \text { to } \\
-0.0385\end{array}$ & & & 14.89 & 21.59 & $95 \%$ CI for $\mathrm{I}^{2}$ & 66.07 to 93.17 \\
\hline Total (fixed effects) & & & 47 & 47 & & & & & -1.195 & 0.233 & -1.657 to -0.733 & -5.138 & $<0.001$ & 100.00 & 100.00 & & \\
\hline Total (random effects) & & & 47 & 47 & & & & & -1.918 & -1.836 & -3.139 to -0.533 & -2.798 & 0.006 & 100.00 & 100.00 & & \\
\hline
\end{tabular}


Table 7. Cont

\begin{tabular}{|c|c|c|c|c|c|c|c|c|c|c|c|c|c|c|c|c|c|}
\hline \multirow[t]{2}{*}{ Authors } & \multicolumn{2}{|c|}{ Carnitine Dosage } & \multirow[t]{2}{*}{ N1 } & \multirow[t]{2}{*}{ N2 } & \multirow[t]{2}{*}{ Mean 1} & \multirow[t]{2}{*}{ SD 1} & \multirow[t]{2}{*}{ Mean 2} & \multirow[t]{2}{*}{ SD 2} & \multirow[t]{2}{*}{ SMD } & \multirow[t]{2}{*}{$\mathrm{SE}$} & \multirow[t]{2}{*}{$95 \% \mathrm{CI}$} & \multirow[t]{2}{*}{$t$} & \multirow[t]{2}{*}{$p$} & \multicolumn{2}{|c|}{ Weight (\%) } & \multicolumn{2}{|c|}{ Test for Heterogeneity } \\
\hline & & & & & & & & & & & & & & Fixed & Random & & \\
\hline Arenas 1994 & $2 \mathrm{~g}$ & $4 \mathrm{w}$ & 7 & 7 & 30.9 & 3.8 & 34.8 & 3.4 & -1.012 & 0.536 & -2.179 to 0.155 & & & 24.52 & 25.62 & $\mathrm{Q}$ & 20.4203 \\
\hline Greig 1987 & $2 \mathrm{~g}$ & $4 \mathrm{w}$ & 10 & 10 & 41.3 & 8.4 & 56.0 & 8.2 & -1.696 & 0.505 & -2.758 to -0.634 & & & 27.55 & 26.03 & DF & 3 \\
\hline Oyono-Enguelle 1988 & $2 \mathrm{~g}$ & $4 \mathrm{w}$ & 10 & 10 & 62.0 & 3.8 & 79.8 & 3.8 & -4.486 & 0.829 & -6.227 to -2.745 & & & 10.25 & 21.37 & $\mathrm{I}^{2}$ & $85.31 \%$ \\
\hline Total (fixed effects) & & & 37 & 37 & & & & & -1.311 & 0.265 & -1.839 to -0.782 & -4.942 & $<0.001$ & 100.00 & 100.00 & $95 \% \mathrm{CI}$ for $\mathrm{I}^{2}$ & 63.69 to 94.06 \\
\hline Total (random effects) & & & 37 & 37 & & & & & -1.757 & 0.718 & -3.187 to -0.326 & -2.448 & 0.017 & 100.00 & 100.00 & & \\
\hline \multirow[t]{2}{*}{ Authors } & $\begin{array}{c}\text { Carn. } \\
\text { Dosage }\end{array}$ & Training & N1 & N2 & Mean 1 & SD 1 & Mean 2 & SD 2 & SMD & SE & $95 \% \mathrm{CI}$ & $\mathrm{t}$ & $p$ & \multicolumn{2}{|c|}{ Weight (\%) } & \multicolumn{2}{|c|}{ Test for Heterogeneity } \\
\hline & & & & & & & & & & & & & & Fixed & Random & & \\
\hline Arenas 1991 Runners & $\underset{\mathrm{w}}{\mathrm{g} / \mathrm{d}, 3}$ & $\begin{array}{c}\text { After } \\
\text { exercise }\end{array}$ & 13 & 13 & 26.3 & 1.9 & 29.0 & 2.7 & -1.120 & 0.410 & -1.967 to -0.273 & & & 58.88 & 58.09 & Q & 1.0969 \\
\hline Arenas 1991 Sprinters & $1 \mathrm{~g} / \mathrm{d}, 3$ & $\begin{array}{c}\text { After } \\
\text { exercise }\end{array}$ & 11 & 11 & 21.6 & 1.5 & 24.3 & 1.4 & -1.790 & 0.491 & -2.814 to -0.766 & & & 41.12 & 41.91 & DF & 1 \\
\hline Total (fixed effects) & & & 24 & 24 & & & & & -1.396 & 0.315 & -2.029 to -0.762 & -4.432 & $<0.001$ & 100.00 & 100.00 & Significance level & $p=0.2949$ \\
\hline \multirow[t]{2}{*}{ Total (random effects) } & & & 24 & 24 & & & & & -1.401 & 0.331 & -2.066 to -0.735 & -4.236 & $<0.001$ & 100.00 & 100.00 & $\mathrm{I}^{2}$ & $8.83 \%$ \\
\hline & & & & & & & & & & & & & & & & $95 \% \mathrm{CI}_{\text {for }} \mathrm{I}^{2}$ & 0.00 to 0.00 \\
\hline
\end{tabular}

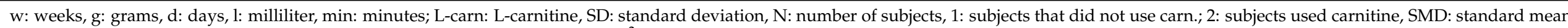
differences, SE: standard error, CI: confidential intervals, SD: standard deviation, $\mathrm{I}^{2}$ : inconsistency. 
Table 8. Serum free carnitine $(\mu \mathrm{mol} / \mathrm{L})$ at rest with and without L-carnitine supplementation and serum free carnitine after exercise with and without L-carnitine supplementation.

\begin{tabular}{|c|c|c|c|c|c|c|c|c|c|c|c|c|c|c|c|c|c|}
\hline \multirow[t]{2}{*}{ Authors } & \multicolumn{2}{|c|}{ Carnitine Dosage } & N1 & $\mathrm{N} 2$ & Mean 1 & SD 1 & Mean 2 & SD 2 & SMD & SE & $95 \%$ CI & $t$ & $p$ & \multicolumn{2}{|c|}{ Weight (\%) } & \multicolumn{2}{|c|}{ Test for Heterogeneity } \\
\hline & & & & & & & & & & & & & & Fixed & Random & $\mathrm{Q}$ & 72.6140 \\
\hline $\begin{array}{c}\text { Arenas } 1991 \\
\text { runner }\end{array}$ & \multicolumn{2}{|c|}{$1 \mathrm{~g} / \mathrm{d}, 3 \mathrm{w}$} & 13 & 13 & 40.0 & 3 & 38.0 & 5 & 0.470 & 0.385 & -0.326 to 1.265 & & & 15.50 & 9.84 & DF & 10 \\
\hline Arenas 1991 sprinter & \multicolumn{2}{|c|}{$2 \mathrm{~g} / \mathrm{d}, 3 \mathrm{w}$} & 11 & 11 & 34.0 & 4 & 36.0 & 3 & -0.544 & 0.418 & -1.417 to 0.328 & & & 13.16 & 9.70 & $\mathrm{I}^{2}$ (inconsistency) & $86.23 \%$ \\
\hline Arenas 1994 & \multicolumn{2}{|c|}{$2 \mathrm{~g} / \mathrm{d}, 4 \mathrm{w}$} & 7 & 7 & 27.8 & 3.5 & 31.7 & 2.9 & -1.136 & 0.544 & -2.322 to 0.0504 & & & 7.77 & 9.08 & $95 \% \mathrm{CI}_{\text {for }} \mathrm{I}^{2}$ & 77.18 to 91.69 \\
\hline Colombani 1996 & \multicolumn{2}{|c|}{$4 \mathrm{~g} / \mathrm{d}, 1 \mathrm{~d}$} & 7 & 7 & 41.5 & 2.9 & 45.8 & 2.0 & -1.616 & 0.586 & -2.893 to -0.339 & & & 6.70 & 8.86 & & \\
\hline Cooper 1986 & \multicolumn{2}{|c|}{$4 \mathrm{~g} / \mathrm{d}, 10 \mathrm{~d}$} & 10 & 10 & 35.4 & 8.9 & 33.1 & 7.9 & 0.262 & 0.430 & -0.642 to 1.166 & & & 12.44 & 9.64 & & \\
\hline Gorostiag 1989 & \multicolumn{2}{|c|}{$2 \mathrm{~g} / \mathrm{d}, 4 \mathrm{w}$} & 10 & 10 & 31.4 & 1.7 & 39.2 & 3.3 & -2.846 & 0.621 & -4.151 to -1.541 & & & 5.97 & 8.67 & & \\
\hline Muller 2002 & \multicolumn{2}{|c|}{$3 \mathrm{~g} / \mathrm{d}, 10 \mathrm{~d}$} & 10 & 10 & 41.10 & 6.54 & 52.74 & 9.23 & -1.394 & 0.482 & -2.405 to -0.382 & & & 9.92 & 9.40 & & \\
\hline Oyono-Enguelle 1989 & \multicolumn{2}{|c|}{$2 \mathrm{~g} / \mathrm{d}, 3 \mathrm{w}$} & 10 & 10 & 49.8 & 2.3 & 59.4 & 3.9 & -2.872 & 0.624 & -4.183 to -1.560 & & & 5.91 & 8.66 & & \\
\hline Oyono-Enguelle 1989 & \multicolumn{2}{|c|}{$2 \mathrm{~g} / \mathrm{d}, 4 \mathrm{w}$} & 10 & 10 & 49.8 & 2.3 & 64.1 & 3.7 & -4.445 & 0.823 & -6.175 to -2.716 & & & 3.40 & 7.57 & & \\
\hline Oyono-Enguelle 1989 & \multicolumn{2}{|c|}{$2 \mathrm{~g} / \mathrm{d}, 12 \mathrm{w}$} & 10 & 10 & 49.8 & 2.3 & 48.0 & 3.5 & 0.582 & 0.438 & -0.338 to 1.502 & & & 12.00 & 9.61 & & \\
\hline Total fixed effects & & & 104 & 104 & & & & & -0.787 & 0.152 & -1.086 to -0.488 & -5.189 & $<0.001$ & 100.00 & 100.00 & & \\
\hline Total random effects & & & 104 & 104 & & & & & -1.216 & 0.416 & -2.036 to -0.395 & -2.921 & 0.004 & 100.00 & 100.00 & & \\
\hline \multirow[t]{2}{*}{ Authors } & $\begin{array}{c}\text { Carn. } \\
\text { Dosage }\end{array}$ & Training & N1 & N2 & Mean 1 & SD 1 & Mean 2 & SD 2 & SMD & SE & $95 \% \mathrm{CI}$ & $t$ & $p$ & \multicolumn{2}{|c|}{ Weight (\%) } & \multicolumn{2}{|c|}{ Test for Heterogeneity } \\
\hline & & & & & & & & & & & & & & Fixed & Random & Q & 24.4106 \\
\hline Arenas 1991 runner & $\underset{\mathrm{w}}{\mathrm{g} / \mathrm{d}, 3}$ & $\begin{array}{c}\text { After } \\
\text { running }\end{array}$ & 13 & 13 & 22.9 & 1.8 & 25.7 & 2.6 & SMD & $\mathrm{SE}$ & $95 \% \mathrm{CI}$ & & & $\begin{array}{c}\text { Weight } \\
(\%)\end{array}$ & SMD & Significance level & $p=0.0004$ \\
\hline Arenas 1991 sprinter & $2 \mathrm{~g} / \mathrm{d}, 3$ & $\begin{array}{c}\text { After } \\
\text { running }\end{array}$ & 11 & 11 & 18.2 & 1.5 & 21.0 & 1.7 & -1.680 & 0.482 & -2.686 to -0.675 & & & Fixed & 10.38 & $\mathrm{I}^{2}$ (inconsistency) & $75.42 \%$ \\
\hline Colombani1996 & $4 \mathrm{~g} / \mathrm{d}, 1 \mathrm{~d}$ & $\begin{array}{c}\text { After } \\
\text { running }\end{array}$ & 7 & 7 & 45.8 & 2.0 & 70.0 & 4.9 & -1.213 & 0.415 & -2.070 to -0.355 & & & 20.37 & -1.213 & $95 \% \mathrm{CI}_{\text {for }} \mathrm{I}^{2}$ & 48.00 to 88.38 \\
\hline Cooper 1986 & $\begin{array}{c}4 \mathrm{~g} / \mathrm{d}, 10 \\
\mathrm{~d}\end{array}$ & $\begin{array}{c}\text { After } 158^{\prime} \\
\text { of } \\
\text { Marathon }\end{array}$ & 10 & 10 & 22.5 & 2.8 & 35.0 & 12.6 & -1.680 & 0.482 & -2.686 to -0.675 & & & 15.13 & -1.680 & & \\
\hline Gorostiaga1989 & $\underset{\mathrm{w}}{2 \mathrm{~g} / \mathrm{d}, 4}$ & $\begin{array}{l}\text { After } 40^{\prime} \\
\text { of } \\
\text { exercise }\end{array}$ & 10 & 10 & 35.5 & 4.4 & 38.9 & 2.8 & -6.052 & 1.248 & -8.772 to -3.332 & & & 2.26 & -6.052 & & \\
\hline Marconi 1985 & $\underset{\mathrm{w}}{\mathrm{g} / \mathrm{d}, 2}$ & $\begin{array}{l}\text { After } 120^{\prime} \\
\text { of } \\
\text { treadmill }\end{array}$ & 6 & 6 & 56.8 & 9.6 & 62.5 & 11.6 & -1.312 & 0.476 & -2.311 to -0.312 & & & 15.52 & -1.312 & & \\
\hline Nuesch 1999 & $1 \mathrm{~g} / \mathrm{d}$ & $\begin{array}{l}10^{\prime} \text { after } \\
\text { maximal } \\
\text { treadmill }\end{array}$ & 9 & 9 & 71.3 & 10.2 & 71.8 & 10.7 & -0.883 & 0.450 & -1.829 to 0.0635 & & & 17.32 & -0.883 & & \\
\hline Total (fixed effects) & & & 66 & 66 & & & & & -0.494 & 0.542 & -1.702 to 0.714 & -5.660 & $<0.001$ & 11.96 & -0.494 & & \\
\hline Total (random effects) & & & 66 & 66 & & & & & -0.0455 & 0.449 & -0.997 to 0.906 & -3.253 & 0.001 & 17.44 & -0.0455 & & \\
\hline
\end{tabular}


Table 8. Cont.

\begin{tabular}{|c|c|c|c|c|c|c|c|c|c|c|c|c|c|c|c|c|}
\hline \multirow[t]{2}{*}{ Authors } & \multirow[t]{2}{*}{ Carnitine Dosage } & \multirow[t]{2}{*}{ N1 } & \multirow[t]{2}{*}{ N2 } & \multirow[t]{2}{*}{ Mean 1} & \multirow[t]{2}{*}{ SD 1} & \multirow[t]{2}{*}{ Mean 2} & \multirow[t]{2}{*}{ SD 2} & \multirow[t]{2}{*}{ SMD } & \multirow[t]{2}{*}{$\mathrm{SE}$} & \multirow[t]{2}{*}{$95 \% \mathrm{CI}$} & \multirow[t]{2}{*}{$t$} & \multirow[t]{2}{*}{$p$} & \multicolumn{2}{|c|}{ Weight (\%) } & \multicolumn{2}{|c|}{ Test for Heterogeneity } \\
\hline & & & & & & & & & & & & & Fixed & Random & & \\
\hline Arenas 1991 sprinter & $2 \mathrm{~g} / \mathrm{d}, 3 \mathrm{w}$ & 11 & 11 & 34.0 & 4 & 36.0 & 3 & -0.544 & 0.418 & -1.417 to 0.328 & & & 69.01 & 51.98 & $\mathrm{Q}$ & 9.5950 \\
\hline Oyono-Enguelle 1989 & $2 \mathrm{~g} / \mathrm{d}, 3 \mathrm{w}$ & 10 & 10 & 49.8 & 2.3 & 59.4 & 3.9 & -2.872 & 0.624 & -4.183 to -1.560 & & & 30.99 & 48.02 & DF & 1 \\
\hline \multirow[t]{2}{*}{ Total random effects } & & 21 & 21 & & & & & -1.662 & 1.163 & -4.012 to 0.688 & -1.429 & 0.161 & 100.00 & 100.00 & $\mathrm{I}^{2}$ & $89.58 \%$ \\
\hline & & & & & & & & & & & & & & & $95 \% \mathrm{CI}$ for $\mathrm{I}^{2}$ & 61.34 to $97.1 \mathrm{~s}$ \\
\hline Arenas 1994 & $2 \mathrm{~g} / \mathrm{d}, 4 \mathrm{w}$ & 7 & 7 & 27.8 & 3.5 & 31.7 & 2.9 & -0.959 & 0.631 & -2.413 to 0.495 & & & 41.10 & 41.10 & $\mathrm{Q}$ & 0.03256 \\
\hline Gorostiaga 1989 & $2 \mathrm{~g} / \mathrm{d}, 4 \mathrm{w}$ & 10 & 10 & 31.4 & 1.7 & 39.2 & 3.3 & -0.888 & 0.785 & -2.664 to 0.888 & & & 26.51 & 26.51 & $\mathrm{DF}$ & 2 \\
\hline Oyono-Enguelle 1989 & $2 \mathrm{~g} / \mathrm{d}, 4 \mathrm{w}$ & 10 & 10 & 49.8 & 2.3 & 64.1 & 3.7 & -1.075 & 0.710 & -2.657 to 0.508 & & & 32.39 & 32.39 & Significance level & $p=0.9839$ \\
\hline Total fixed effects & & 27 & 27 & & & & & -0.978 & 0.404 & -1.801 to -0.154 & -2.418 & 0.021 & 100.00 & 100.00 & $\mathrm{I}^{2}$ & $0.00 \%$ \\
\hline Total random effects & & 27 & 27 & & & & & -0.978 & 0.404 & -1.801 to -0.154 & -2.418 & 0.021 & 100.00 & 100.00 & $95 \% \mathrm{CI}_{\text {for I }} \mathrm{I}^{2}$ & 0.00 to 0.00 \\
\hline
\end{tabular}

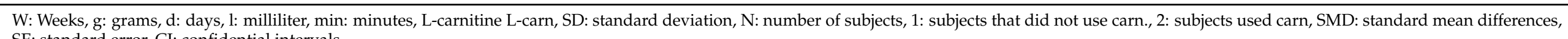
SE: standard error, CI: confidential intervals. 
All study groups were not homogeneous for relevant general features, such as age, sex and physical performance. Other characteristics of the studies were the supplementation dosage and duration of dietary intake, metabolic parameters used for the assessment of physical performance after L-carnitine intake and follow up (Table 1). In addition, the participants were submitted to different kinds and durations of physical exercise. Only a few studies were included in the meta-analysis because of sample inhomogeneity and the lack of quantitative measures.

\subsection{Participants, Interventions and Comparators}

The studies included in the systematic review met the PICOS criteria [11]. This systematic review included original studies on L-carnitine supplementation in healthy subjects (Table 1). In all of the studies, the participants were healthy adults, the elderly or athletes. The studies of obese subjects with metabolic disorders were excluded, but healthy overweight individuals were included.

The studies described the effects of dietary L-carnitine supplementation, comparing no intake, different dosages, different periods of follow-up, at rest and after physical exercise.

The outcomes included clinical assessments and metabolic parameters. All the studies used validated measurement tools and clearly showed their results. The design of the studies was RCT, retrospective and prospective studies, according to the recommendations of the Oxford Centre for Evidence-Based Medicine (Table 1). The meta-analysis focused on the quantitative results of metabolic parameters that were reported in more than one article.

\subsection{Meta-Analysis Results}

A total of 15 studies were included in the meta-analysis (Tables 4-8). Pooling of data within the meta-analysis revealed that several measures including serum lactate at rest (Table 4) and after exercise (Table 5) did not present significant variations with and without L-carnitine administration $(p>0.05)$. On the contrary, significant variations of $\mathrm{VO}_{2}$ at rest $(p<0.005)$ (Table 6), and serum total and free carnitine at rest and after exercise (Tables 7 and 8$)(p<0.001)$ and after L-carnitine administration were found.

The dosage of supplementation that obtained a significant change in serum total carnitine was $2 \mathrm{~g} / \mathrm{dL}$ for 4 weeks at rest and $1 \mathrm{~g} / \mathrm{dL}$ for 3 weeks after exercise (Table 7), and in serum free carnitine it was $2 \mathrm{~g} / \mathrm{dL}$ for 3 weeks and $2 \mathrm{~g} / \mathrm{dL}$ for 4 weeks at rest (Table 8 ). The data were not sufficient to obtain statistically significant values for $\mathrm{VO}_{2}$ and plasma lactate.

\subsection{Heterogeneity and Publication Bias}

The risk of bias assessment of the individual studies is presented in Table 1 and in the funnel plot (Figures 2-6).

As shown in Tables 4-8, the Inconsistency test $\left(\mathrm{I}^{2}\right)$ verified the impact of study heterogeneity on the results of the meta-analysis. The heterogeneity between studies was very low for plasma lactate at rest $\left(\mathrm{I}^{2}=0.00 \%\right.$ ) (Table 4 ) and after exercise $\left(\mathrm{I}^{2}=0.00 \%\right)$ (Table 5$)$, low for $\mathrm{VO}_{2}\left(\mathrm{I}^{2}=0-36 \%\right)$ (Table 6) and moderate for serum carnitine (0-89\%) (Tables 7 and 8 ). The asymmetry between the studies, which is visible in the funnel plot (Tables 4-7), can be explained by the heterogeneity of the sample; for this reason, publication bias and the small study effect were not significant. 
Colombani 1996

Chun 2011

Chun 2011

Chun 2011

Chun 2011

Chun 2011

Greig 1987

Greig 1987

Oyono-Enguelle 1988

Watcher 2002

Wyss 1990

Total (fixed effects)

Total (random effects)

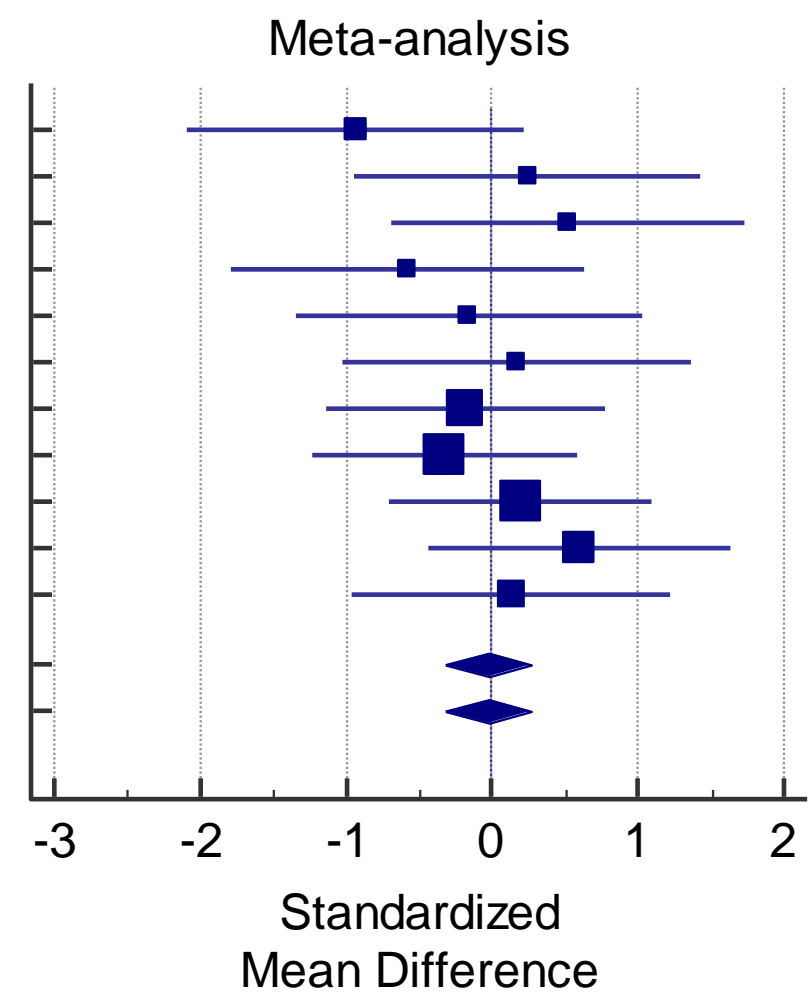

Meta-analysis

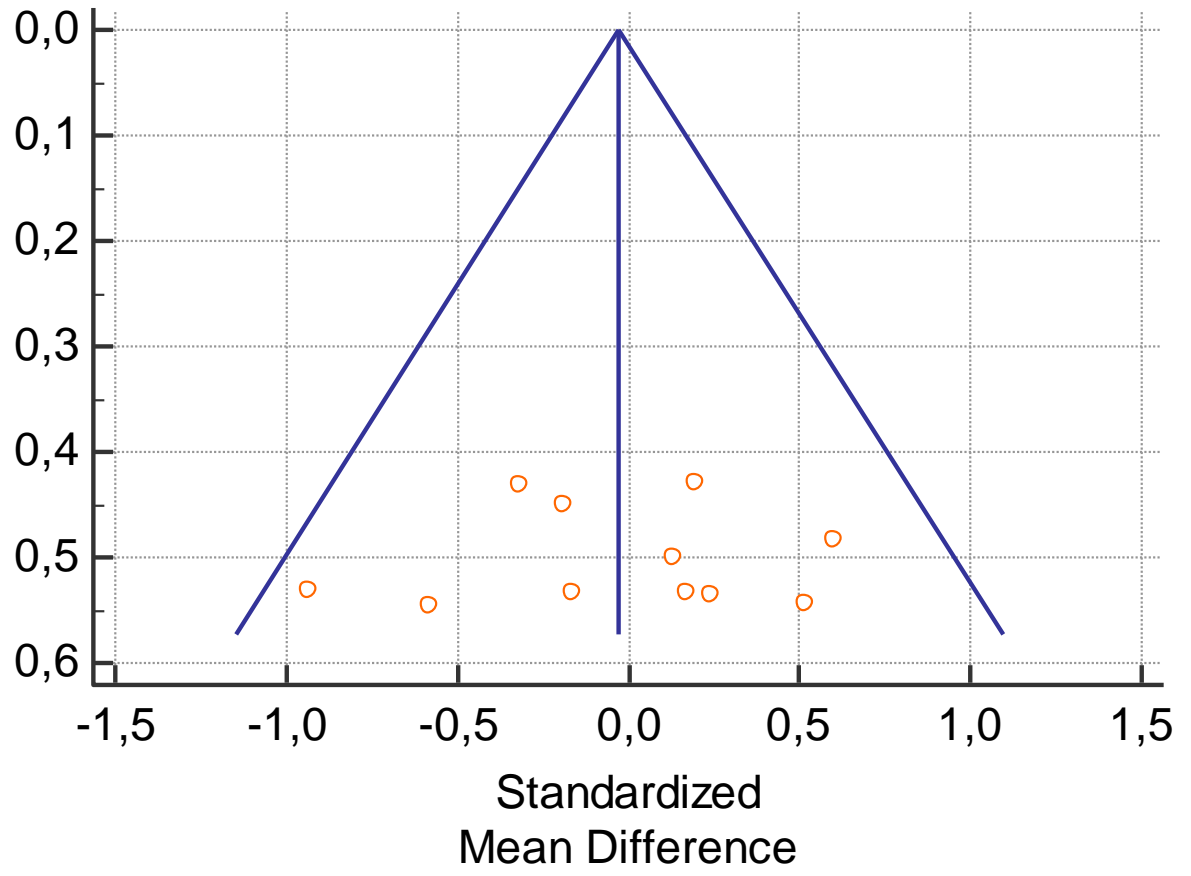

(a)

Figure 2. Cont. 

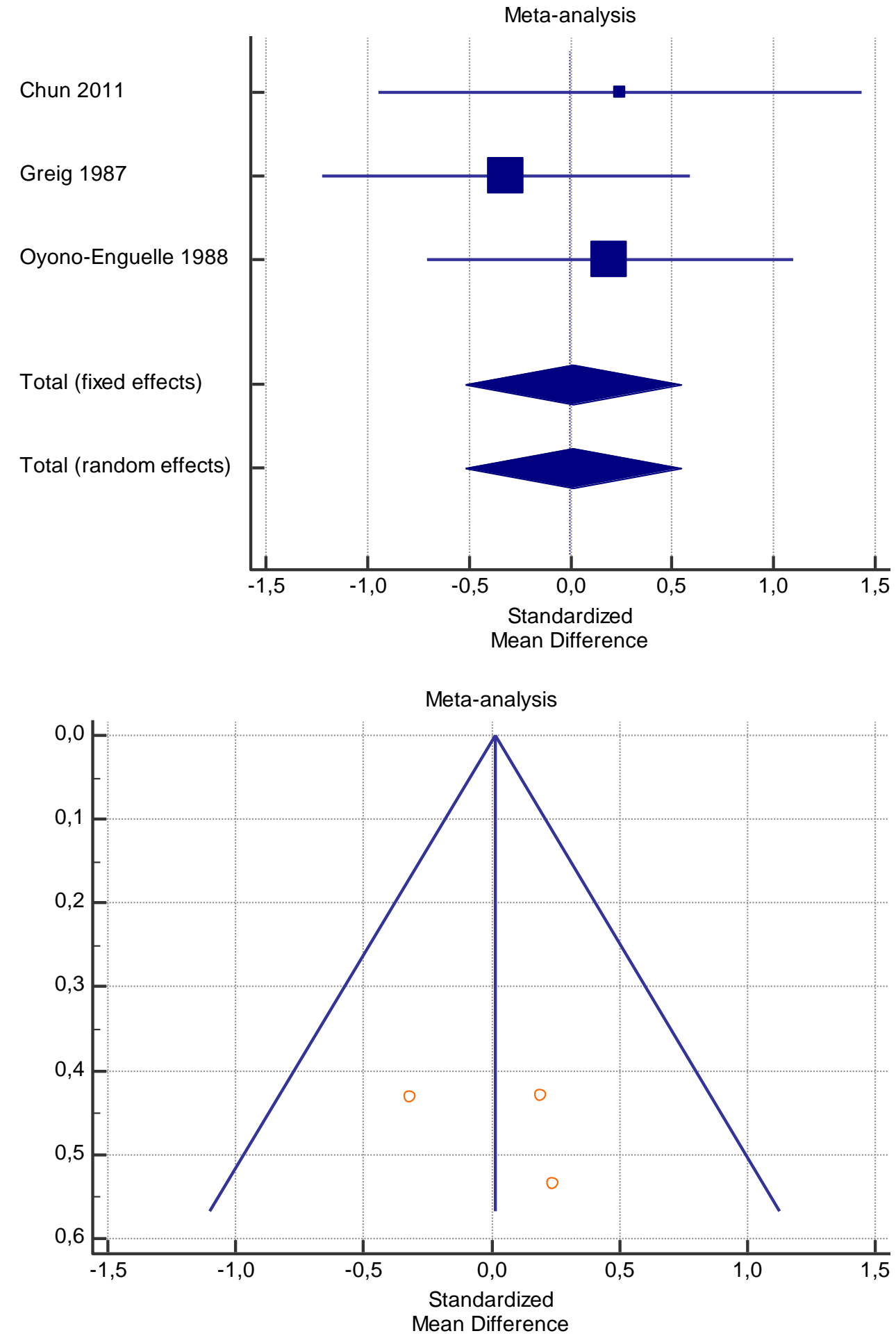

(b)

Figure 2. (a) Graphic correlation to Table 4: Plasma lactate $(\mathrm{mmol} / \mathrm{L})$ at rest with and without Lcarnitine supplementation. (b) Graphic correlation to Table 4: Plasma lactate (mmol/L) after $2 \mathrm{~g} / \mathrm{dL}$ for 4 weeks of L-carnitine supplementation. 
Colombani 1996

Chun 2011

Chun 2011

Chun 2011

Chun 2011

Chun 2011

Greig 1987

Greig 1987

Koozehchian2018

Oyono-Enguelle 1988

Watcher 2002

Wyss 1990

Total (fixed effects)

Total (random effects)
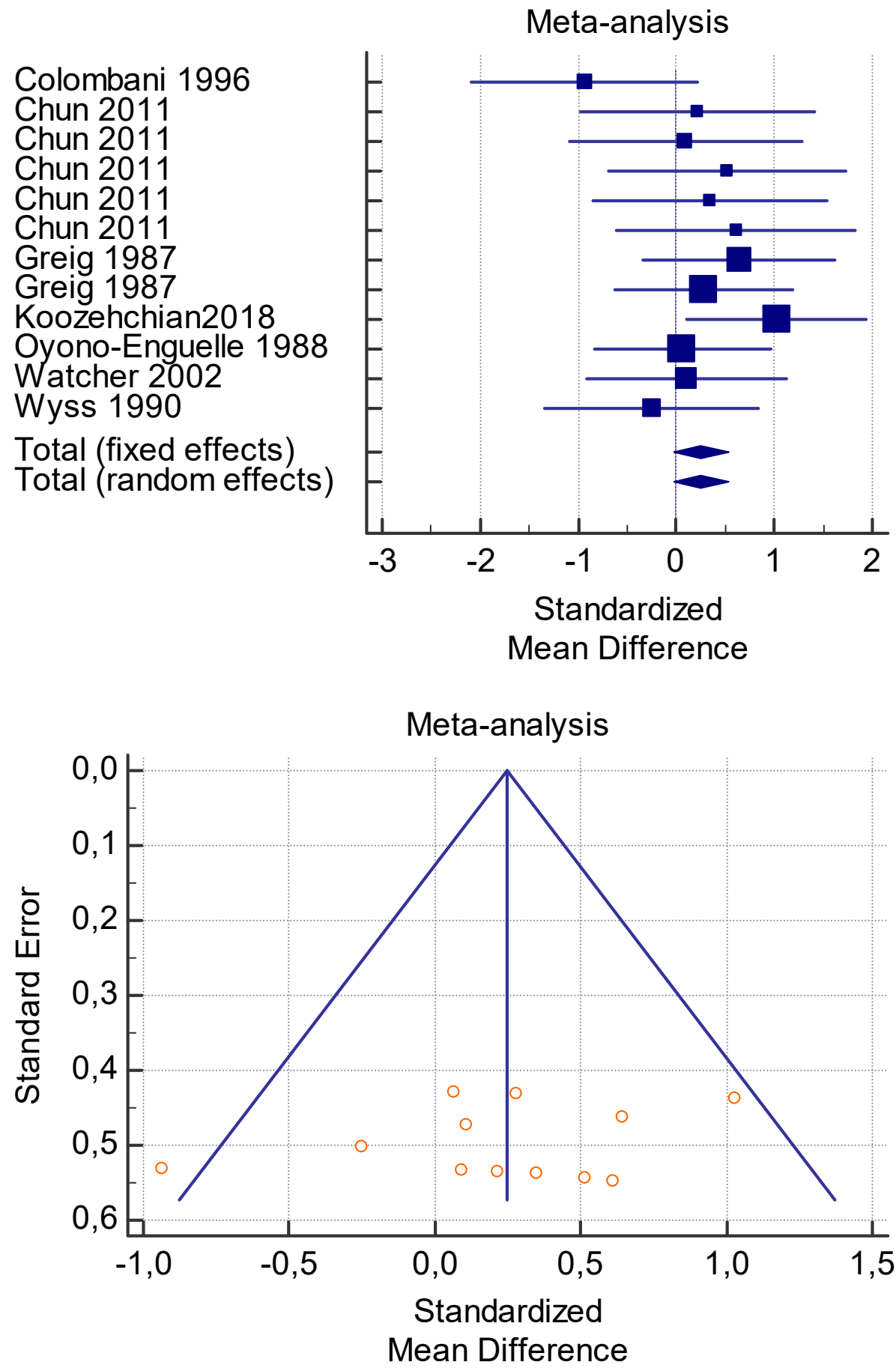

(a)

Figure 3. Cont. 

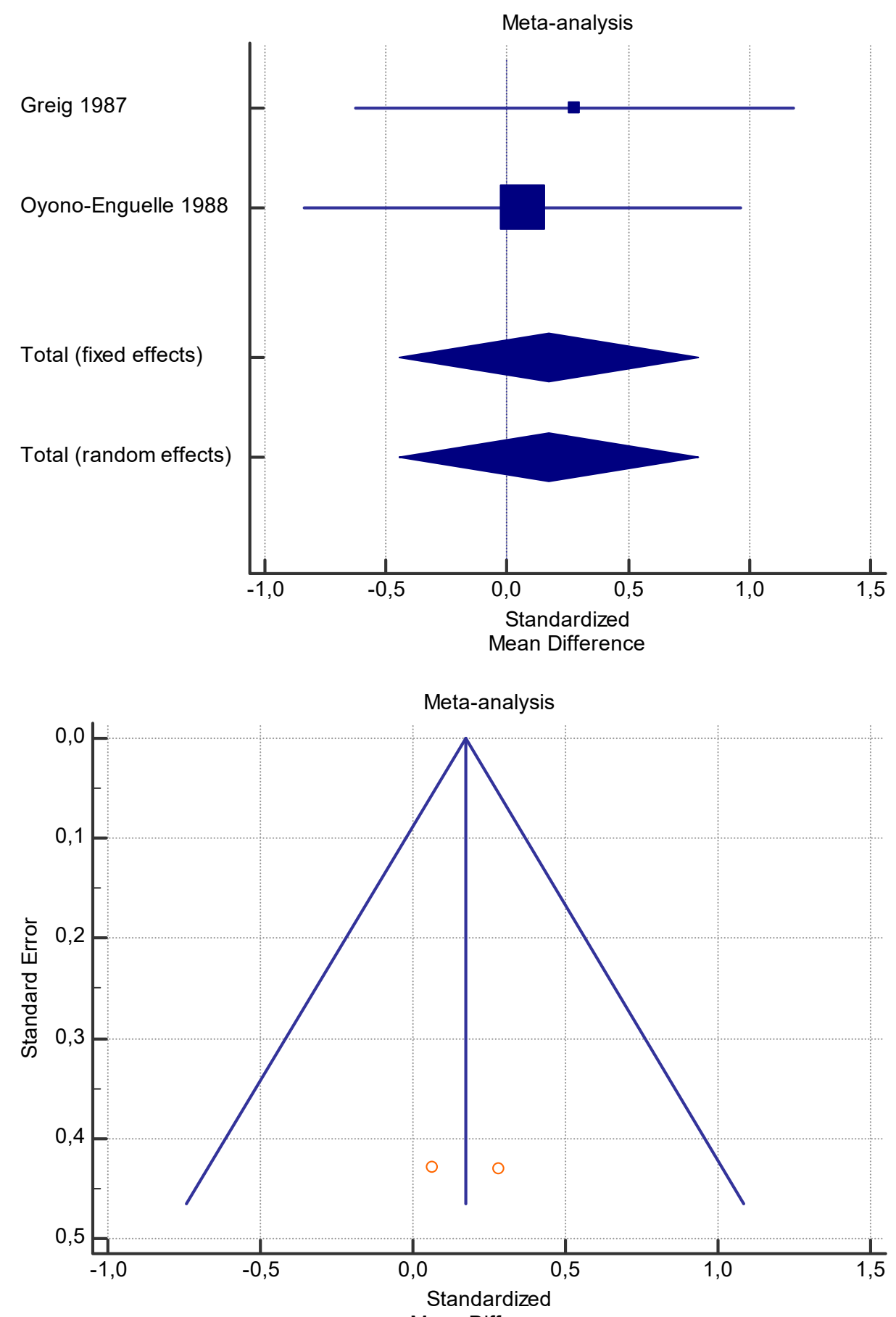

Mean Difference

(b)

Figure 3. (a) Graphic correlation to Table 5: Plasma lactate (mmol/L) after exercise with and without and L-carnitine supplementation. (b) Graphic correlation to Table 5: Plasma lactate (mmol/L) after exercise after $2 \mathrm{~g} / \mathrm{dL}$ for 4 weeks of L-carnitine supplementation. 
Chun 2011

Chun 2011

Chun 2011

Chun 2011

Chun 2011

Greig 1987

Greig 1987

Marconi 1985

Parandak2014

Vecchiet 1990

Wachter 2002

Total (fixed effects)

Total (random effects)

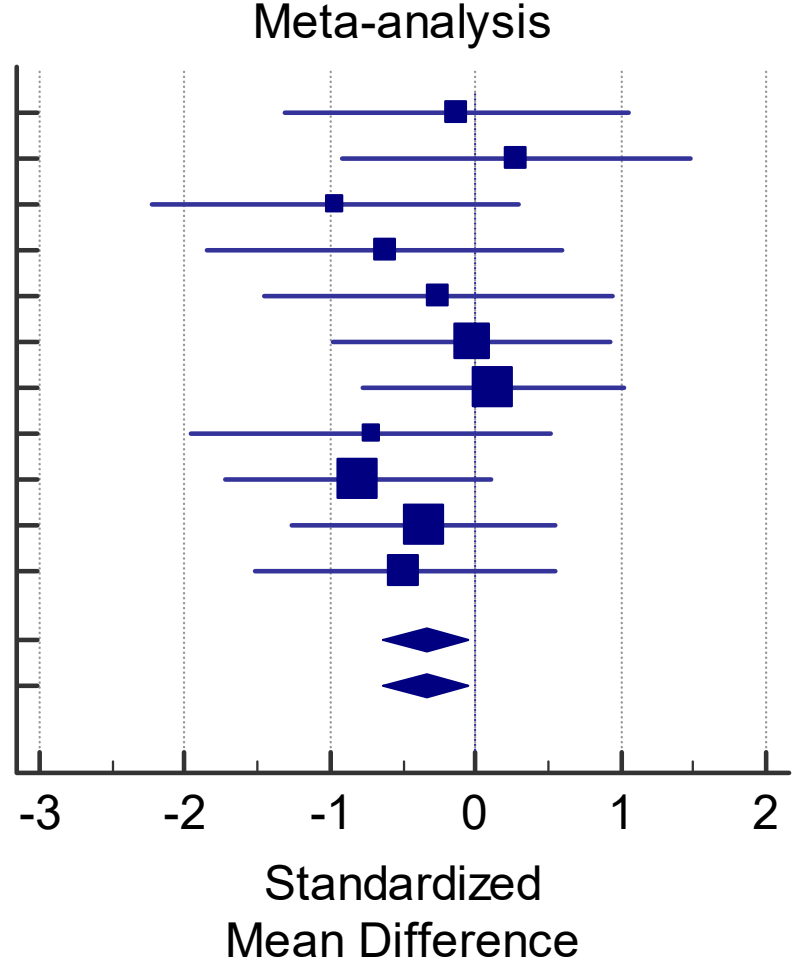

Meta-analysis

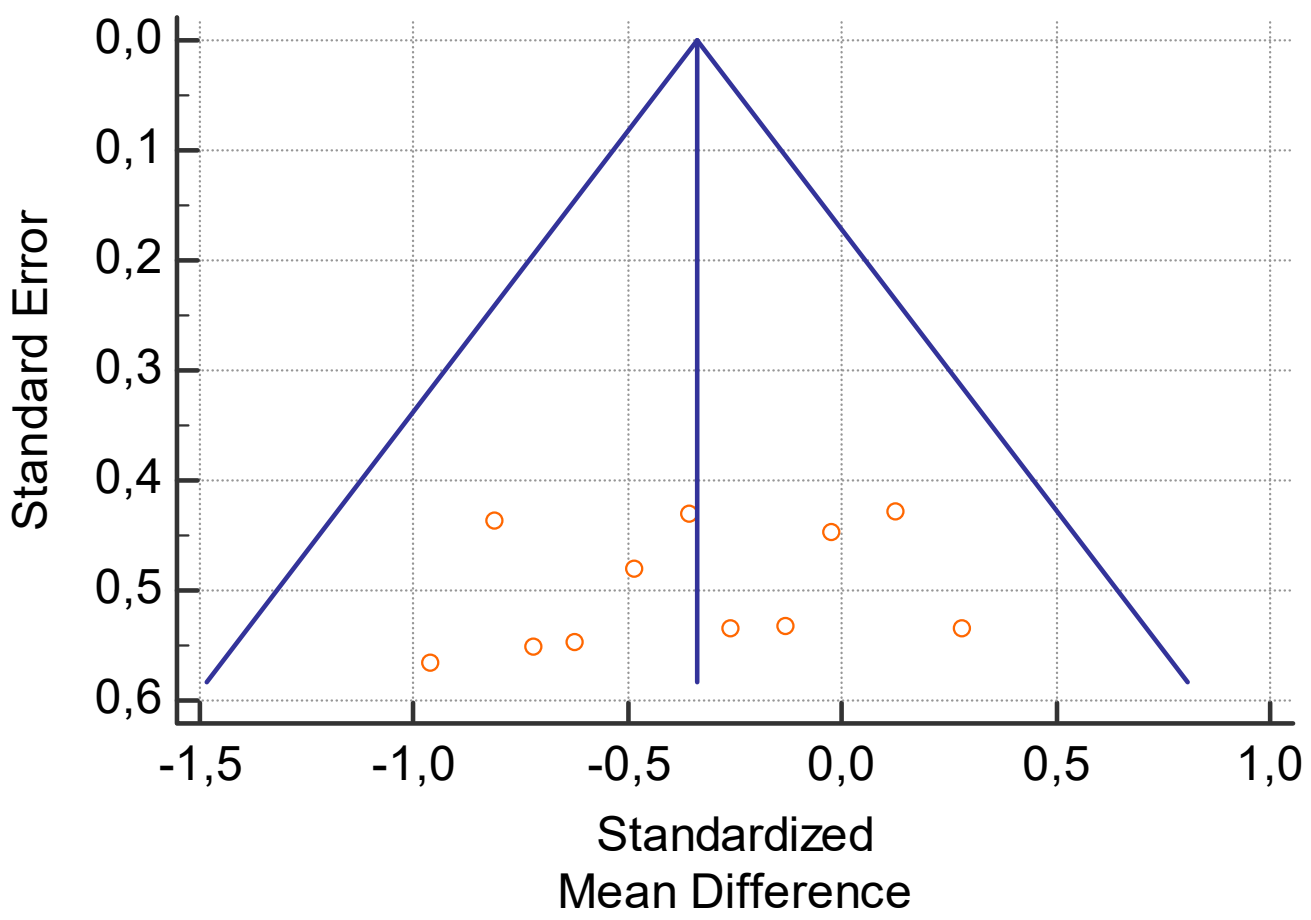

(a)

Figure 4. Cont. 

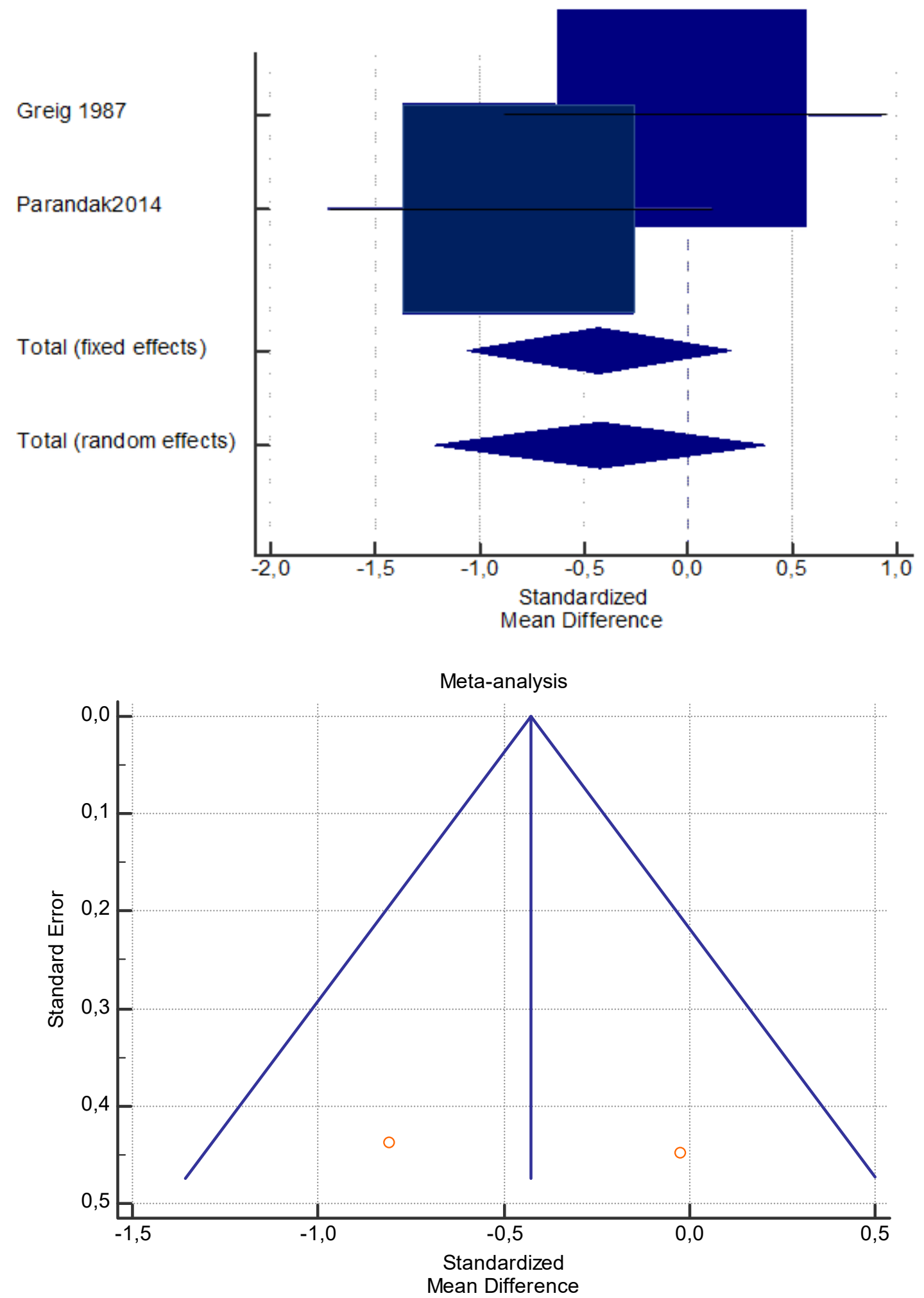

(b)

Figure 4. Cont. 

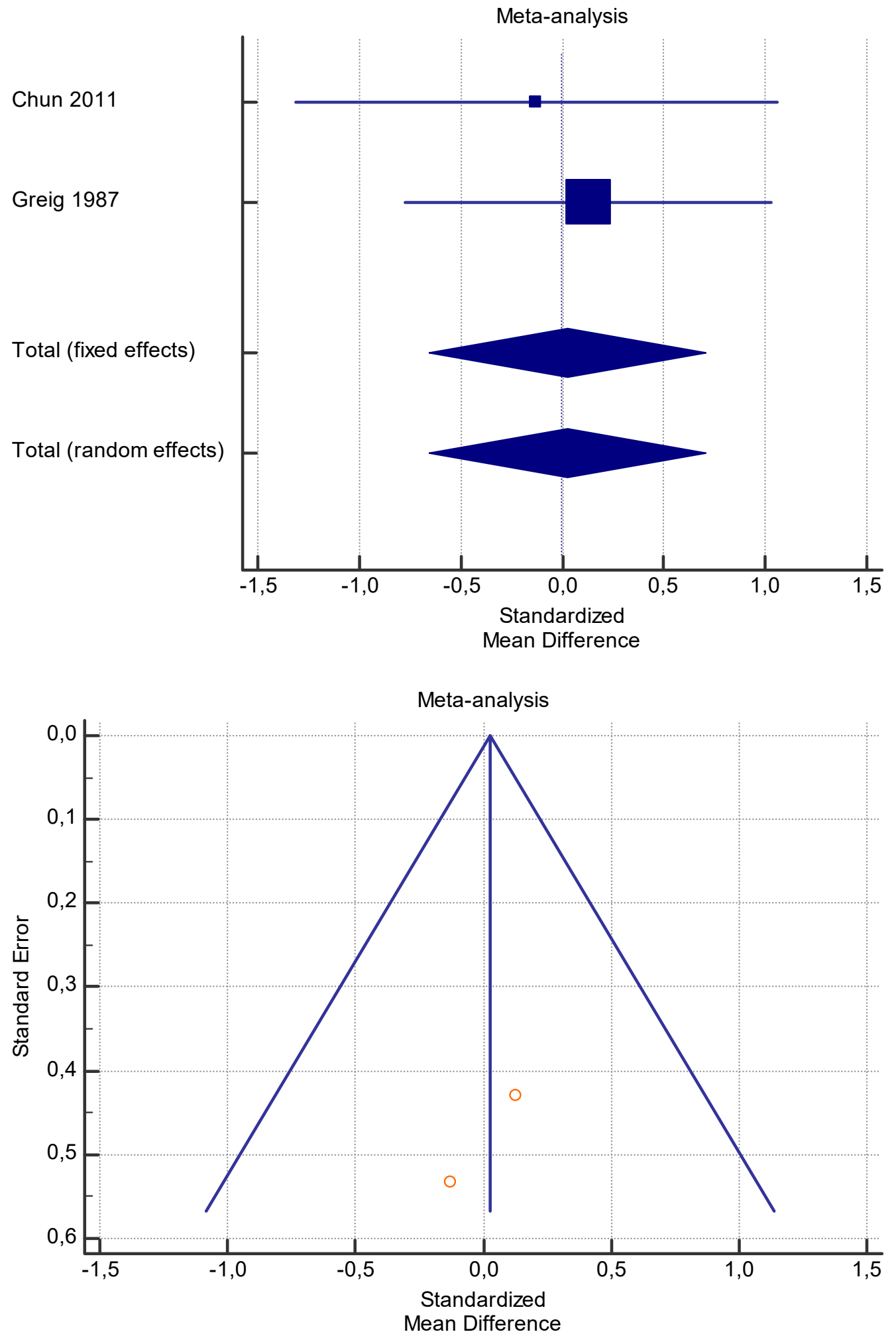

(c)

Figure 4. (a) Graphic correlation to Table 6: Maximal oxygen consumption $\mathrm{VO}_{2}(\mathrm{~mL} / \mathrm{min} / \mathrm{kg})$ at rest with and without the L-carnitine supplementation. (b) Graphic correlation to Table 6: Maximal oxygen consumption $\mathrm{VO}_{2}(\mathrm{~mL} / \mathrm{min} / \mathrm{kg})$ at rest after $2 \mathrm{~g} / \mathrm{dL}$ for 2 weeks of L-carnitine supplementation. (c) Graphic correlation to Table 5: Maximal oxygen consumption $\mathrm{VO}_{2}(\mathrm{~mL} / \mathrm{min} / \mathrm{kg})$ at rest after $2 \mathrm{~g} / \mathrm{dL}$ for 4 weeks of L-carnitine supplementation. 
Meta-analysis

Arenas 1991 Sprinters

Arenas 1991 Sprinters

Arenas 1994

Colombani 1996

Gorostiaga 1989

Greig 1987

Greig 1987

Marconi 1985

Muller 2002

Oyono-enguelle 1988

Oyono-enguelle 1988

Oyono-enguelle 1988

Swart 1997

Total (fixed effects)

Total (random effects)

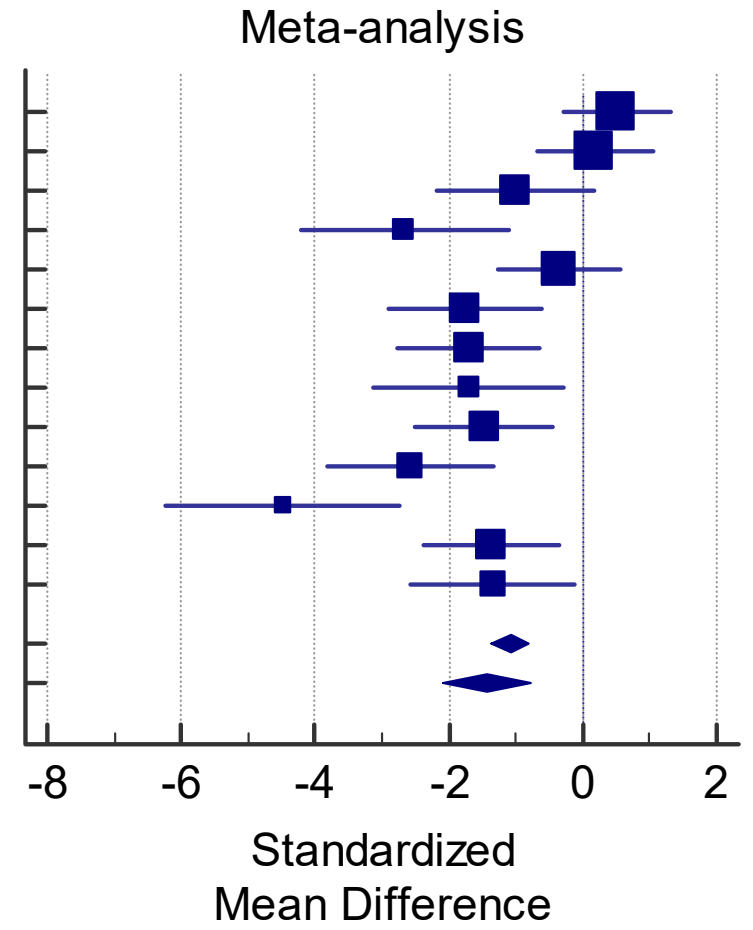

Meta-analysis

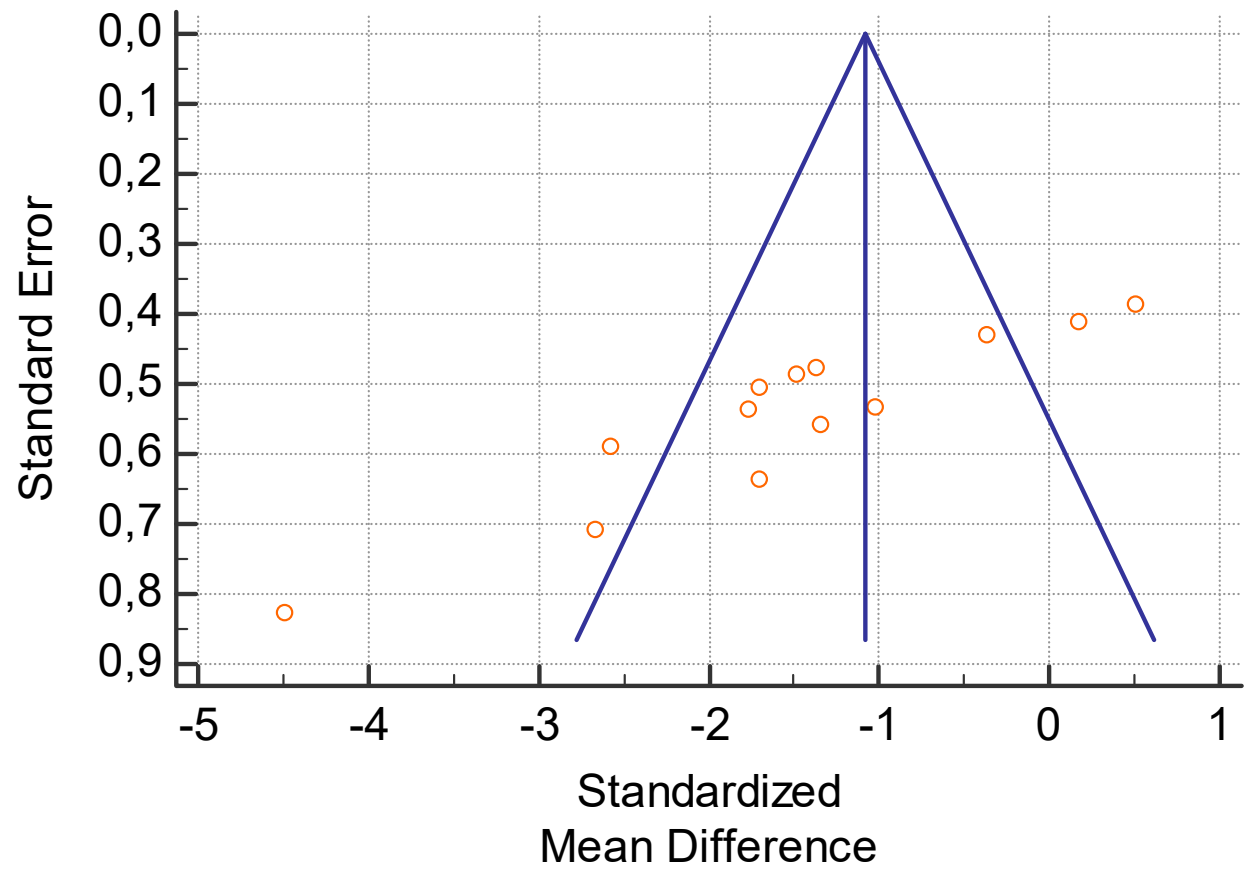

(a)

Figure 5. Cont. 

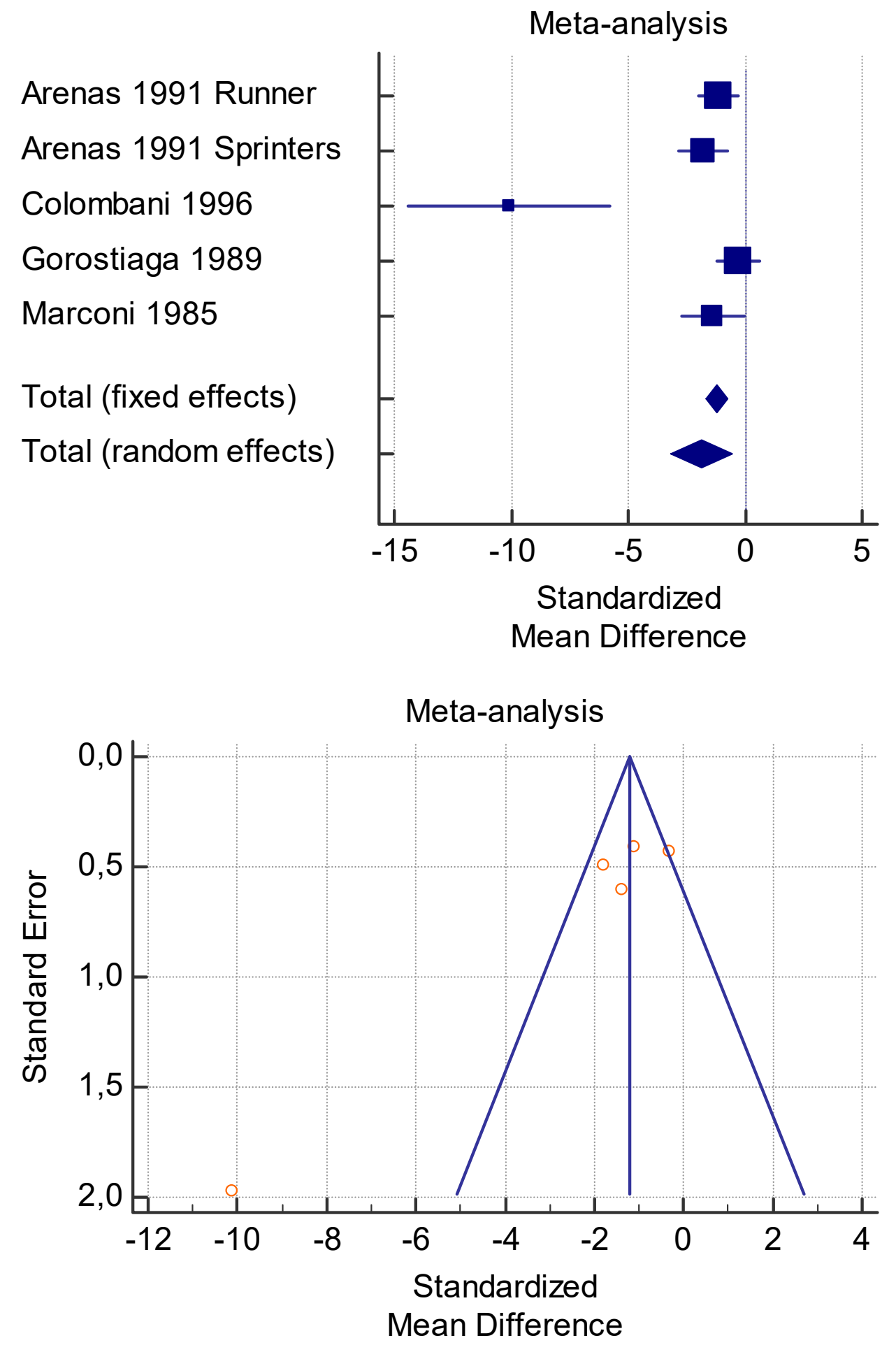

(b)

Figure 5. Cont. 

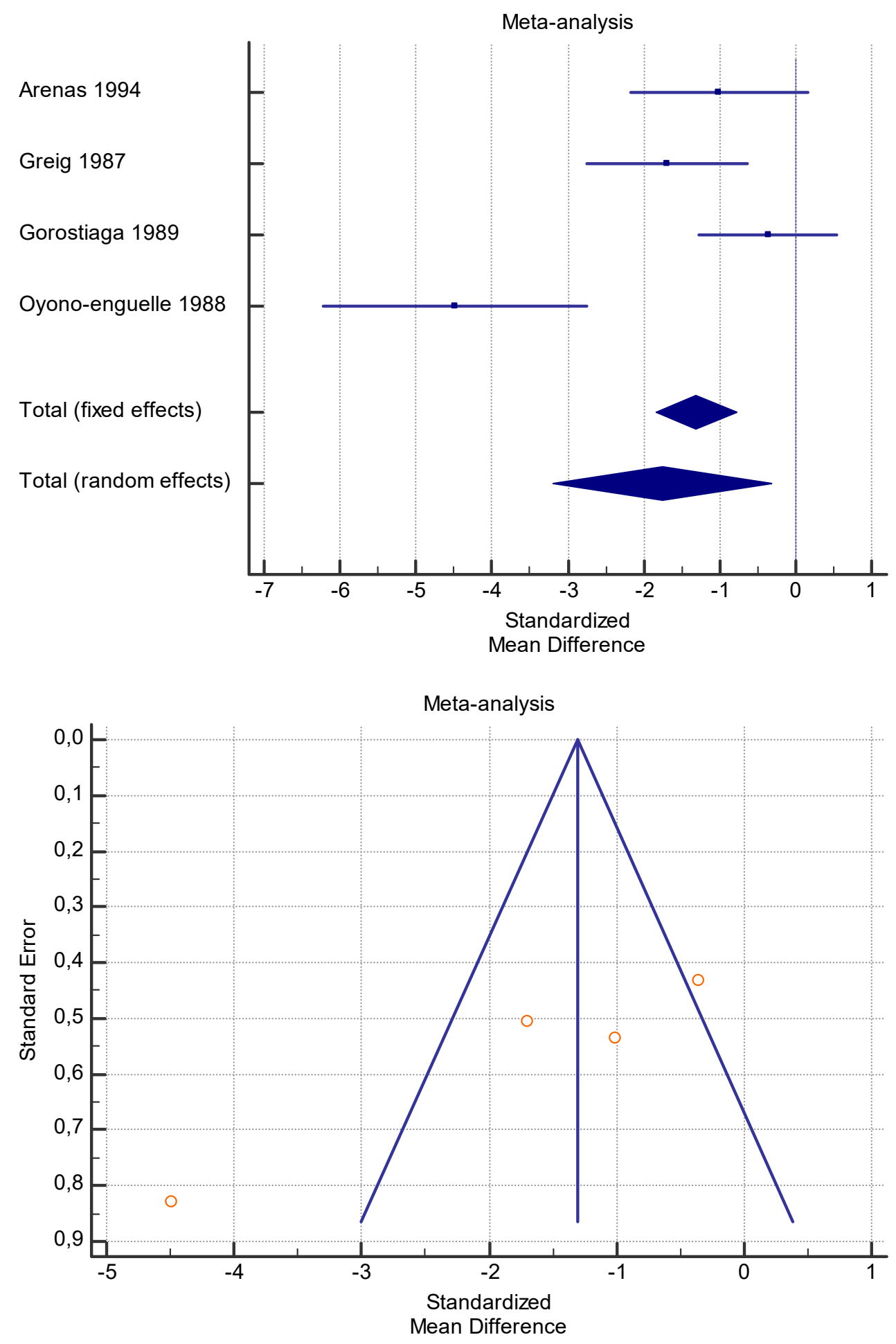

(c)

Figure 5. Cont. 

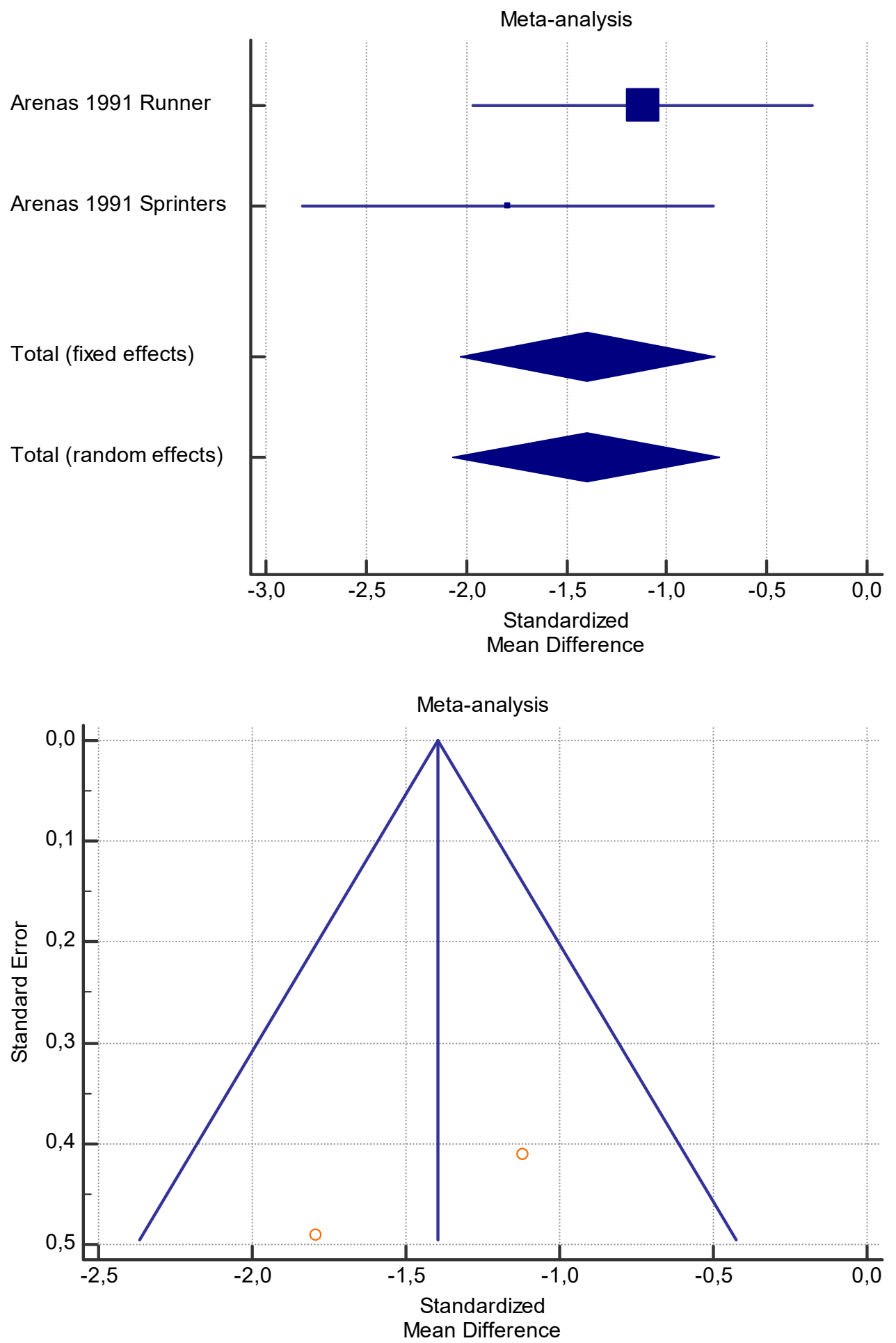

(d)

Figure 5. (a) Graphic correlation to Table 7: Serum total carnitine ( $\mu \mathrm{mol} / \mathrm{L})$ at rest with and without the L-carnitine supplementation. (b) Graphic correlation to Table 7: Serum total carnitine ( $\mu \mathrm{mol} / \mathrm{L}$ ) after exercise with and without the L-carnitine supplementation. (c) Graphic correlation to Table 7: Serum total carnitine $(\mu \mathrm{mol} / \mathrm{L})$ at rest after $2 \mathrm{~g} / \mathrm{dL}$ for 4 weeks of L-carnitine supplementation. (d) Graphic correlation to Table 7: Serum total carnitine ( $\mu \mathrm{mol} / \mathrm{L})$ after exercise after $1 \mathrm{~g} / \mathrm{dL}$ for 3 weeks of L-carnitine supplementation. 
Meta-analysis

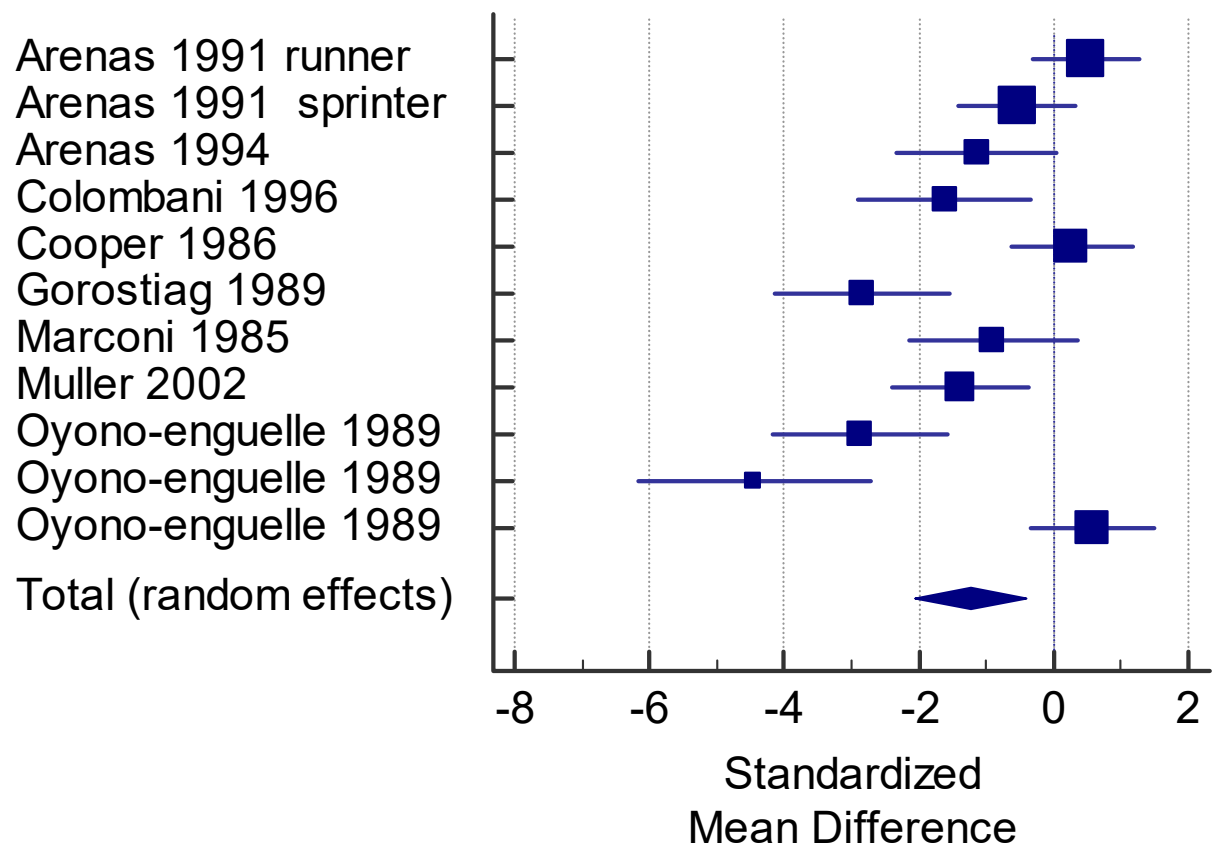

Meta-analysis

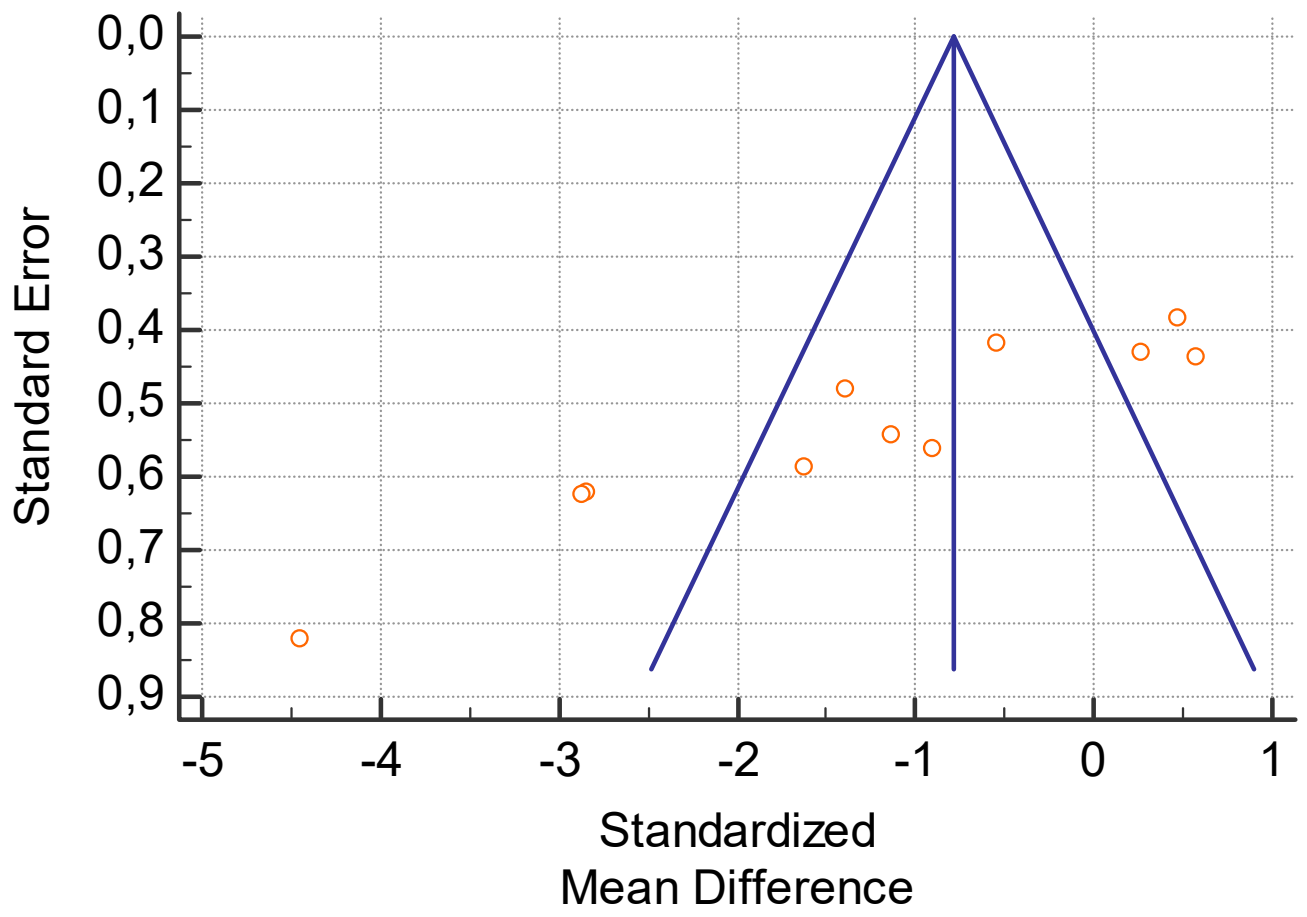

(a)

Figure 6. Cont. 
Meta-analysis

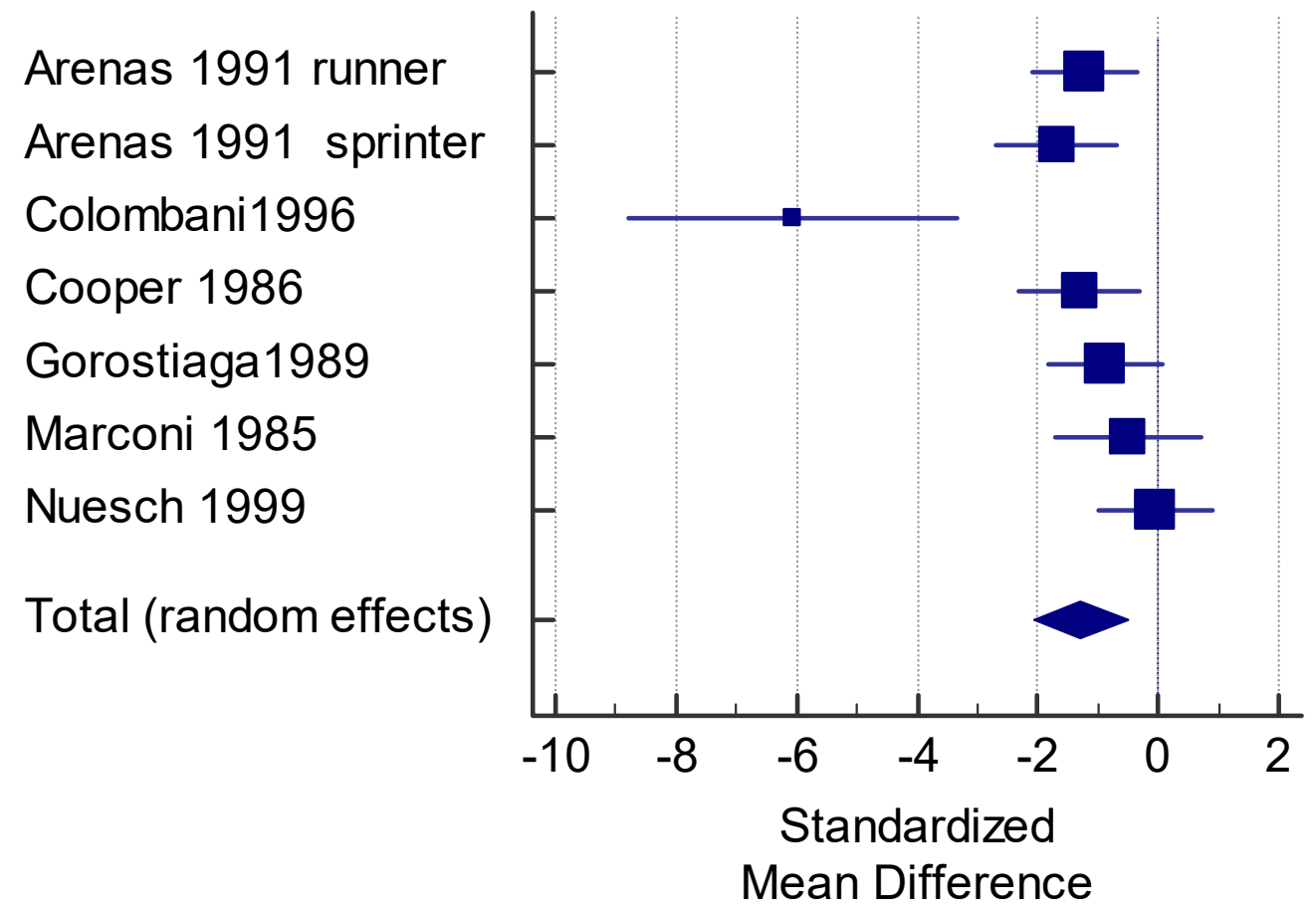

Meta-analysis

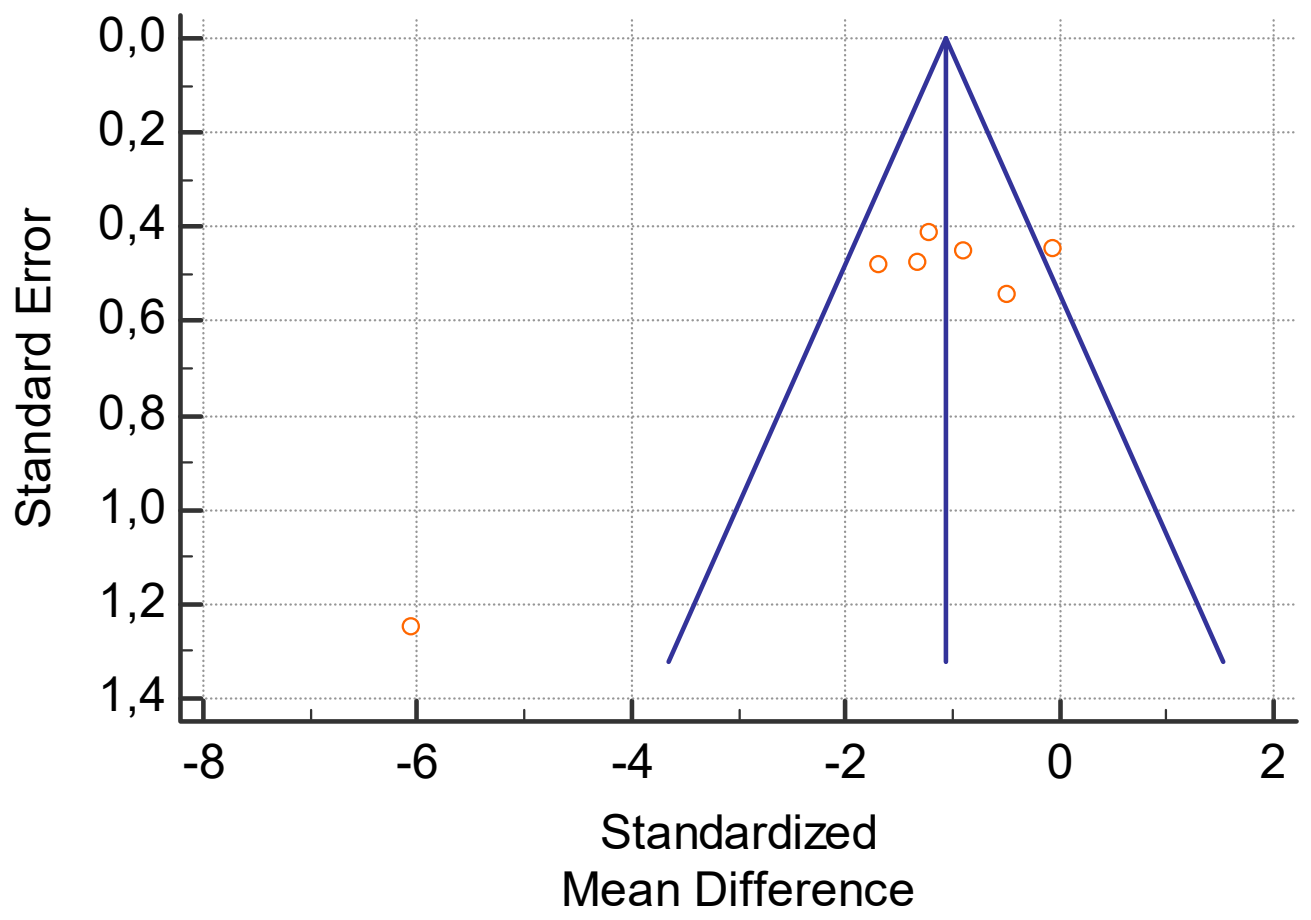

(b)

Figure 6. Cont. 

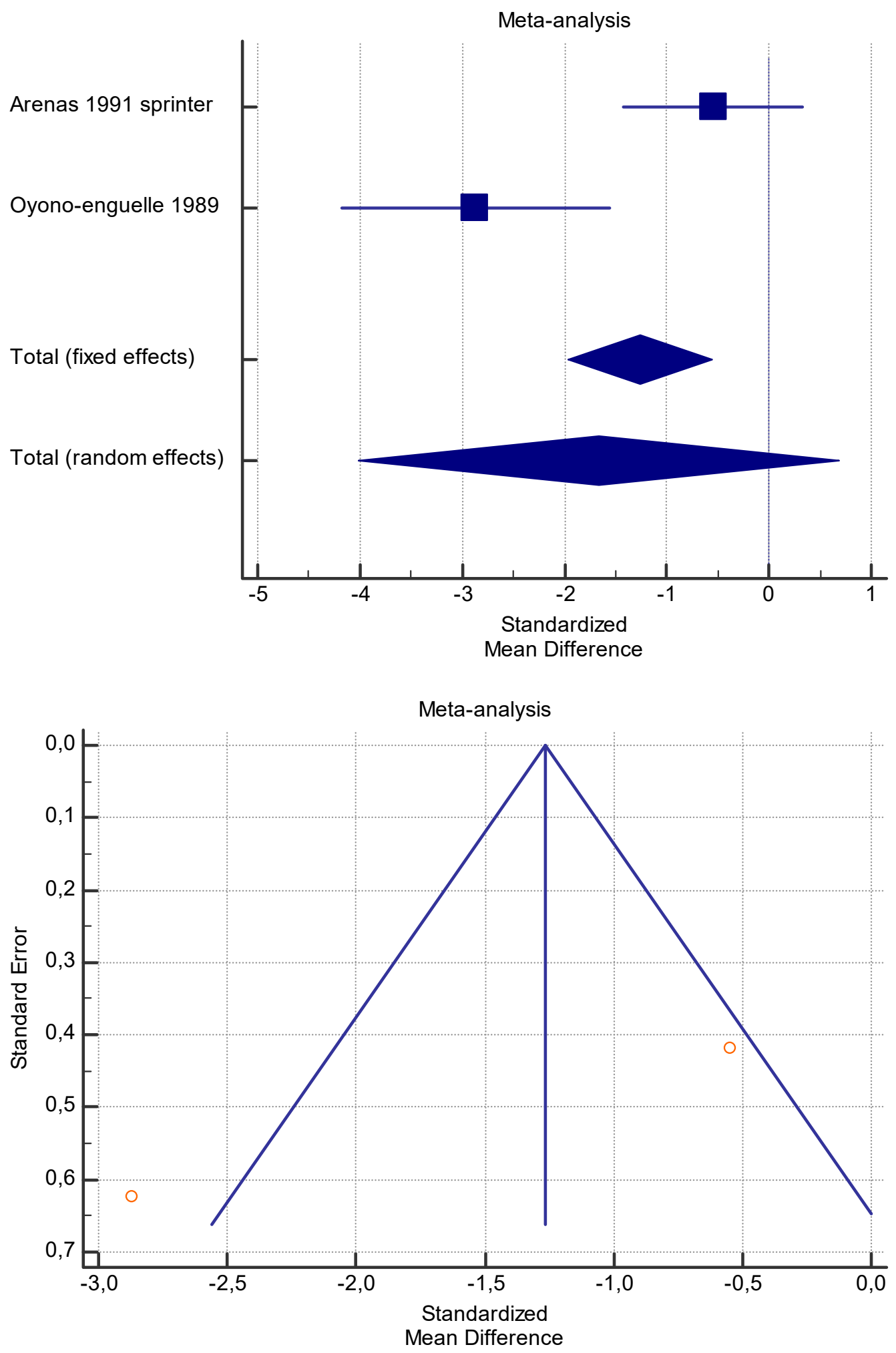

(c)

Figure 6. Cont. 

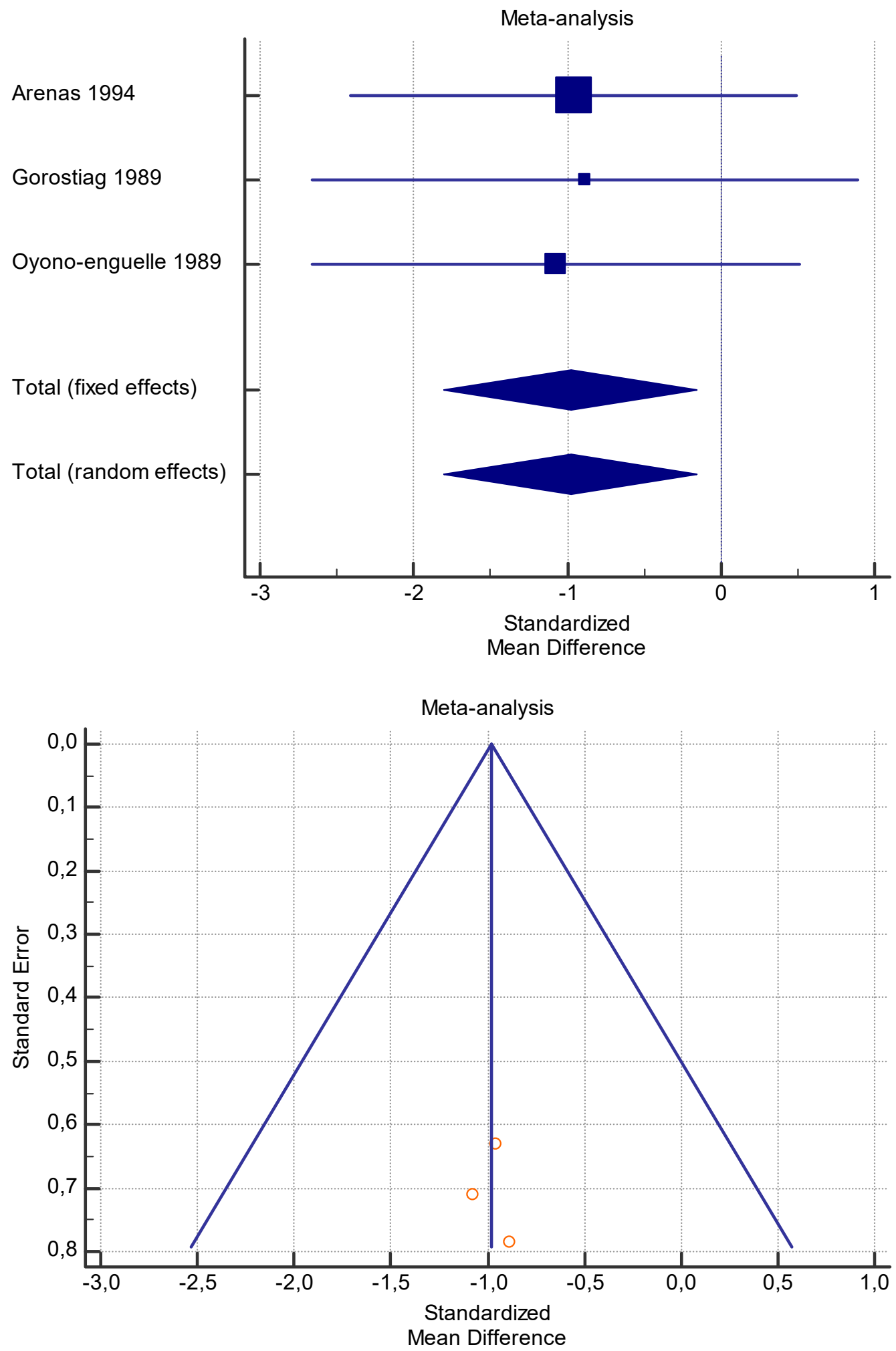

(d)

Figure 6. (a) Graphic correlation to Table 8: Serum free carnitine ( $\mu \mathrm{mol} / \mathrm{L}$ ) at rest with and without the L-carnitine supplementation. (b) Graphic correlation to Table 8: Serum free carnitine ( $\mu \mathrm{mol} / \mathrm{L})$ after exercise with and without the L-carnitine supplementation. (c) Graphic correlation to Table 8: Serum free carnitine ( $\mu \mathrm{mol} / \mathrm{L}$ ) at rest after $2 \mathrm{~g} / \mathrm{dL}$ for 3 weeks of L-carnitine supplementation. (d) Graphic correlation to Table 7: Serum. 


\subsection{Comparing Studies}

The studies described the effects of L-carnitine supplementation on metabolic parameters, muscle features and clinical performance of healthy subjects. (Table 1). Only a few studies did not show a significant difference in muscle carnitine levels [21], muscle and plasma lactate concentration $[21,22], \mathrm{VO}_{2}[21,23,24]$ and physical performance $[22,25]$.

\subsection{Posology and Timeframe}

The literature reported tests on different dosages of supplementation used over different periods of time (Table 1). The administration was made in a single day [21,22,26-28], 2 days [29], 5 days [30], 7 days [31,32], 10 days [33,34], 2 weeks [23,24,35], 3 weeks [36], 4 weeks [1,37-40], 6 weeks [41], 9 weeks [25], 10 weeks [42], 12 weeks [43] and 24 weeks [7].

The supplementation of L-carnitine was commonly administered orally. Only three studies used intravenous L-carnitine $[21,44,45]$.

The effectiveness of the supplementation was not documented by all authors. Greig et al. [24] did not find any beneficial effects after $2 \mathrm{~g}$ for 2 and 4 weeks of oral supplementation and Brass et al. [21] did not show any modification in the content of carnitine in the muscle after a single intravenous dose of $185 \mu \mathrm{mol} / \mathrm{kg}$.

According to the meta-analysis, the dose that was useful for significantly improving the level of plasma lactate was $2 \mathrm{~g} / \mathrm{dL}$ for 12 weeks. The lack of sufficient data did not permit us to delineate the correct dosage to modify serum lactate and $\mathrm{VO}_{2}$.

\section{Discussion}

This study shows the quantity of L-carnitine supplementation needed to obtain physical benefits and reports the metabolic markers especially related to physical activities in healthy people. The effects of the supplementation on physical performance could be applied to rehabilitation, too.

The results of our meta-analysis showed that L-carnitine supplementation had no effect on plasma lactate in individuals at rest and after exercise, neither on $\mathrm{VO}_{2}$ in subjects after exercise. However, the meta-analysis revealed that L-carnitine administration significantly changed serum total carnitine and serum free carnitine at rest and after exercise, as well as $\mathrm{VO}_{2}$ at rest.

Carnitine serum concentration correlated with changes in muscle mass and dietary intake. Moreover, a feeling of fatigue and adherence failure to rehabilitation programs and sports training could reveal values of excessive consumption. L-Carnitine supplementation could increase muscle mass, reduce body fat mass and the perception of fatigue and improve walking ability, especially in the elderly [7,46]. In addition, L-Carnitine supplementation seems to avoid the accumulation of lactate after physical exercise, a value that rises proportionally with training intensity and correlates with training endurance [29]. L-Carnitine supplementation avoids the sports related reduction of $\mathrm{VO}_{2}$ [26] and total and free carnitine [47]. The effectiveness of L-carnitine supplementation is also documented in a reduction of metabolic stress markers and muscle damage [35]. Thanks to these properties, dietary intake of L-carnitine could improve physical performance and increase the adherence to rehabilitation and the duration of training and rehabilitation sessions.

Moreover, the influence of physical activity on the levels of serum creatinine, $\mathrm{VO}_{2}$ and blood lactate makes them possible clinical markers of effectiveness of physical activities and rehabilitation training. In fact, intense physical training seems to increase acylcarnitine levels in muscles [48] and decrease free carnitine [48,49].

Where endurance exercise is concerned, no change was observed after 60 [48], 90 [50] or 225-230 min [51]. According to other studies, carnitine accumulated in muscles and was released later during recovery, based on unchanged total carnitine levels found $60 \mathrm{~min}$ post exercise [48] and $4-5 \mathrm{~h}$ after a marathon [51].

According to some authors, a single administration of L-carnitine before exercise could improve athletic performance with significant changes in free fatty acids, triacylglycerols, lactic acid [44], ability in high-intensity exercise with an increase of $\mathrm{VO}_{2}$ and a decrease 
of plasma lactate and pyruvate [26,29]. Long-term administration of L-carnitine seems to have significative effects on muscle performance, avoiding the reduction of serum total and free muscle carnitine [52] and enhancing the reduction of physical and mental fatigue and the increase of total muscle mass and serum total carnitine [7].

However, not all authors agree on the beneficial effect on muscle substrate [30], muscle carnitine level, muscle lactate accumulation, plasma lactate concentration [21,30] and changes in $\mathrm{VO}_{2} \max [24,30]$.

Several categories of healthy people could benefit from L-carnitine supplementation: healthy adults and the elderly, overweight subjects and athletes. Healthy life expectancy seems to require a good L-carnitine status [42]. Its deficiency is related to elderly frailty; in fact, in the elderly, L-carnitine supplementation seems to increase total muscle mass $[7,46]$ and reduce muscle fatigue [7]. The supplementation of L-carnitine has proven effective for endurance-trained athletes [38], marathon runners [33], long distance competitive walkers [23], long-distance runners and sprinters [37,52], footballers [28] and taekwondo players [32]. In athletes, dietary intake should avoid the reduction of plasma carnitine levels $[38,47]$, and the increase of respiratory quotient $[26,38]$ during maximal and submaximal exercise. Moreover, not only during maximal physical exercise [26], but also during endurance exercises, L-carnitine seems to reduce the concentration or delay the release of blood lactate, and this should improve physical performance, reducing the perception of fatigue [28]. It could decrease heart rate and positively influence aerobic capacity with an increase in running speed [41]. The supplementation should also activate lipid metabolism, facilitating the maintenance of good body weight $[32,44,53,54]$.

\subsection{Implication in Sports and Rehabilitation}

Rehabilitation and physical activity are closely related; in fact, the former promotes the latter [55]. Thanks to this relationship, the positive effect of L-carnitine supplementation on physical performance could also be found in rehabilitation.

Heavy training [56] and high-intensity exercise [57] could cause a reduction in muscle carnitine content; thus, these two eventualities could occur in both sports and rehabilitation. This condition can worsen in the elderly, who often also have a progressive reduction in their total carnitine level linked to aging [58]. L-carnitine intake could reverse these conditions.

The health implications depend on both the carnitine- and sports-related reduction of blood lactate levels, increase of maximal oxygen consumption and fatty acid oxidation [26,59]. All these results support possible implications in rehabilitation with the increase of muscle mass and in sports, improving performance especially during high-intensity and prolonged exercise, even if not always supported by experimental evidence [60].

L-carnitine supplementation improves athletic performance with significant changes in free fatty acids, triacylglycerols, lactic acid [44], ability in high-intensity exercise with an increase of $\mathrm{VO}_{2}$ and a decrease of plasma lactate and pyruvate [26,29], increasing performance during endurance training by attenuating the increase in blood lactate and oxidative stress $[1,25,28,29,38]$.

\subsection{Ineffective Use of L-Carnitine}

A few studies did not confirm the benefits of L-carnitine intake on physical performance [27], neither in muscle carnitine level [21,22], muscle and plasma lactate concentration [21,22], or respiratory exchange ratio [21,23,24]. No improvement was shown, especially after only one single administration of L-carnitine, in physical performance, respiratory exchange ratio, muscle glycogen utilization, plasma $p$-hydroxybutyrate concentration and lactic acid level [21].

\section{Limitations}

Differences in the number of participants, as well as the other heterogeneity characteristics of the samples, may have affected the results of the present review. Moreover, despite 
the total number of clinical trials included in the meta-analysis, the small number of studies included in the assessment of the supplementation dosage did not allow us to evaluate the maximum amount of L-carnitine intake needed to induce changes in the metabolic markers (i.e., $\mathrm{VO}_{2}$ at rest, and after exercise).

\section{Conclusions}

L-carnitine supplementation is used for energetic purposes, to improve physical performance and reverse physical frailty, fatigue and weakness. This study provides a complete overview of the literature concerning the effects of L-carnitine supplementation on physical performance and rehabilitation programs in healthy subjects. Feelings of fatigue and adherence failure to rehabilitation programs and sports training could reveal values of excessive consumption. Thus, L-carnitine supplementation could be added to rehabilitation protocols in individuals whose outcomes are affected by fatigue or excessive physical stress.

Our meta-analysis showed that serum and free carnitine both at rest and after exercise and $\mathrm{VO}_{2}$ at rest are useful markers to follow healthy subjects during physical activity and rehabilitation programs. The dosage of supplementation that obtained a significant change in serum total carnitine was $2 \mathrm{~g} / \mathrm{dL}$ for 4 weeks at rest, $1 \mathrm{~g} / \mathrm{dL}$ for 3 weeks after exercise and in serum free carnitine was $2 \mathrm{~g} / \mathrm{dL}$ for 3 weeks and $2 \mathrm{~g} / \mathrm{dL}$ for 4 weeks at rest. Other robust trials are needed to find the best dosage to obtain positive changes in metabolic parameters and in physical performance.

Author Contributions: M.V. and R.C. conceived and designed the analysis and collected the data; V.P. and G.T. contributed data and analysis tools; M.V. and R.C. performed the analysis; R.C. and M.V. wrote the paper. All authors have read and agreed to the published version of the manuscript.

Funding: This research received no external funding.

Institutional Review Board Statement: Not applicable.

Informed Consent Statement: Not applicable.

Data Availability Statement: All data generated or analyzed during this study are included in this article.

Acknowledgments: The authors wish to thank The Scientific Bureau of the University of Catania, Italy, for language support.

Conflicts of Interest: The authors declare no conflict of interest.

\section{References}

1. Chun, Y.; Lee, K.; Kang, S.; Lee, N.; Kim, J. Influence of L-Carnitine intake for maximal exercise performance and fatigue recovery exercise athletes: Based on elite soccer plaers. Phys. Act. Nutr. 2011, 6, 28-34. [CrossRef]

2. Cruciani, R.A.; Zhang, J.J.; Manola, J.; Cella, D.; Ansari, B.; Fisch, M.J. L-Carnitine Supplementation for the Management of Fatigue in Patients with Cancer: An Eastern Cooperative Oncology Group Phase III, Randomized, Double-Blind, Placebo-Controlled Trial. J. Clin. Oncol. 2012, 30, 3864-3869. [CrossRef]

3. De Simone, C.; Tzantzoglou, S.; Famularo, G.; Moretti, S.; Paoletti, F.; Vullo, V.; Delia, S. High dose L-carnitine improves immunologic and metabolic parameters in AIDS patients. Immunopharmacol. Immunotoxicol. 1993, 15, 1-12. [CrossRef]

4. Siami, G.; Clinton, M.E.; Mrak, R.; Griffis, J.; Stone, W. Evaluation of the Effect of Intravenous L-Carnitine Therapy on Function, Structure and Fatty Acid Metabolism of Skeletal Muscle in Patients Receiving Chronic Hemodialysis. Nephron 1991, 57, 306-313. [CrossRef]

5. Silvério, R.; Laviano, A.; Fanelli, F.R.; Seelaender, M. L-carnitine and cancer cachexia: Clinical and experimental aspects. J. Cachex-Sarcopenia Muscle 2011, 2, 37-44. [CrossRef]

6. Vecchio, M.; Malaguarnera, G.; Giordano, M.; Malaguarnera, M.; Li Volti, G.; Galvano, F.; Drago, F.; Basile, F.; Malaguarnera, M. A Musician's Dystonia. Lancet 2012, 379, 2116. [CrossRef]

7. Malaguarnera, M.; Cammalleri, L.; Gargante, M.P.; Vacante, M.; Colonna, V.; Motta, M. L-Carnitine treatment reduces severity of physical and mental fatigue and increases cognitive functions in centenarians: A randomized and controlled clinical trial. Am. J. Clin. Nutr. 2007, 86, 1738-1744. [CrossRef]

8. Kraemer, W.J.; Volek, J.S.; Spiering, B.A.; Vingren, J.L. L-Carnitine Supplementation: A New Paradigm for its Role in Exercise. Mon. Für Chem. /Chem. Mon. 2005, 136, 1383-1390. [CrossRef] 
9. Shamseer, L.; Moher, D.; Clarke, M.; Ghersi, D.; Liberati, A.; Petticrew, M.; Shekelle, P.; Stewart, L.A. Preferred reporting items for systematic review and meta-analysis protocols (PRISMA-P) 2015: Elaboration and explanation. BMJ 2015, 350, 7647. [CrossRef] [PubMed]

10. Stroup, D.F.; Berlin, J.A.; Morton, S.C.; Olkin, I.; Williamson, G.D.; Rennie, D.; Moher, D.; Becker, B.J.; Sipe, T.A.; Thacker, S.B.; et al. Meta-analysis of Observational Studies in EpidemiologyA Proposal for Reporting. JAMA 2000, 283, 2008-2012. [CrossRef] [PubMed]

11. Methley, A.M.; Campbell, S.; Chew-Graham, C.; McNally, R.; Cheraghi-Sohi, S. PICO, PICOS and SPIDER: A comparison study of specificity and sensitivity in three search tools for qualitative systematic reviews. BMC Health Serv. Res. 2014, 14, 579. [CrossRef]

12. Higgins, J.P.T.; Green, S. (Eds.) Cochrane Handbook for Systematic Reviews of Interventions; Cochrane Collaboration: Oxford, UK, 2008.

13. Guyatt, G.; Oxman, A.D.; Akl, E.A.; Kunz, R.; Vist, G.; Brozek, J.; Norris, S.; Falck-Ytter, Y.; Glasziou, P.; DeBeer, H.; et al. GRADE guidelines: 1. Introduction-GRADE evidence profiles and summary of findings tables. J. Clin. Epidemiol. 2011, 64, 383-394. [CrossRef]

14. Guyatt, G.H.; Oxman, A.D.; Kunz, R.; Brozek, J.; Alonso-Coello, P.; Rind, D.; Devereaux, P.J.; Montori, V.M.; Freyschuss, B.; Vist, G.; et al. GRADE guidelines 6. Rating the quality of evidence-Imprecision. J. Clin. Epidemiol. 2011, 64, 1283-1293. [CrossRef]

15. Guyatt, G.H.; Oxman, A.D.; Vist, G.; Kunz, R.; Brozek, J.; Alonso-Coello, P.; Montori, V.; Akl, E.A.; Djulbegovic, B.; Falck-Ytter, Y. GRADE guidelines: 4. Rating the quality of evidence-Study limitations (risk of bias). J. Clin. Epidemiol. 2011, 64, 407-415. [CrossRef] [PubMed]

16. Guyatt, G.H.; Oxman, A.D.; Montori, V.; Vist, G.; Kunz, R.; Brozek, J.; Alonso-Coello, P.; Djulbegovic, B.; Atkins, D.; Falck-Ytter, Y.; et al. GRADE guidelines: 5. Rating the quality of evidence-Publication bias. J. Clin. Epidemiol. 2011, 64, 1277-1282. [CrossRef] [PubMed]

17. Guyatt, G.H.; Oxman, A.D.; Kunz, R.; Woodcock, J.; Brozek, J.; Helfand, M.; Alonso-Coello, P.; Falck-Ytter, Y.; Jaeschke, R.; Vist, G.; et al. GRADE guidelines: 8. Rating the quality of evidence-indirectness. J. Clin. Epidemiol. 2011, 64, 1303-1310. [CrossRef] [PubMed]

18. Huedo-Medina, T.B.; Sánchez-Meca, J.; Marín-Martínez, F.; Botella, J. Assessing heterogeneity in meta-analysis: Q statistic or $\mathrm{I}^{2}$ index? Psychol. Methods 2006, 11, 193-206. [CrossRef] [PubMed]

19. DerSimonian, R.; Kacker, R. Random-effects model for meta-analysis of clinical trials: An update. Contemp. Clin. Trials 2007, 28, 105-114. [CrossRef]

20. Higgins, J.P.; Altman, D.G.; Gøtzsche, P.C.; Jüni, P.; Moher, D. The Cochrane Collaboration's tool for assessing risk of bias in randomised trials. Br. Med. J. 2011, 343, 889-893. [CrossRef]

21. Brass, E.P.; Hoppel, C.L.; Hiatt, W.R. Effect of intravenous L-carnitine on carnitine homeostasis and fuel metabolism during exercise in humans. Clin. Pharmacol. Ther. 1994, 55, 681-692. [CrossRef]

22. Colombani, P.; Wenk, C.; Kunz, I.; Krähenbühl, S.; Kuhnt, M.; Arnold, M.; Frey-Rindova, P.; Frey, W.; Langhans, W. Effects of L-carnitine supplementation on physical performance and energy metabolism of endurance-trained athletes: A double-blind crossover field study. Eur. J. Appl. Physiol. Occup. Physiol. 1996, 73, 434-439. [CrossRef] [PubMed]

23. Marconi, C.; Sassi, G.; Carpinelli, A.; Cerretelli, P. Effects of L-carnitine loading on the aerobic and anaerobic performance of endurance athletes. Eur. J. Appl. Physiol. Occup. Physiol. 1985, 54, 131-135. [CrossRef]

24. Greig, C.; Finch, K.M.; Jones, D.A.; Cooper, M.; Sargeant, A.J.; Forte, C.A. The effect of oral supplementation with 1-carnitine on maximum and submaximum exercise capacity. Graefe's Arch. Clin. Exp. Ophthalmol. 1987, 56, 457-460. [CrossRef] [PubMed]

25. Koozehchian, M.S.; Daneshfar, A.; Fallah, E.; Agha-Alinejad, H.; Samadi, M.; Kaviani, M.; Kaveh B, M.; Jung, Y.P.; Sablouei, M.H.; Moradi, N.; et al. Effects of nine weeks L-Carnitine supplementation on exercise performance, anaerobic power, and exerciseinduced oxidative stress in resistance-trained males. J. Exerc. Nutr. Biochem. 2018, 22, 7-19. [CrossRef]

26. Vecchiet, L.; Di Lisa, F.; Pieralisi, G.; Ripari, P.; Menabò, R.; Giamberardino, M.A.; Siliprandi, N. Influence of L-carnitine administration on maximal physical exercise. Eur. J. Appl. Physiol. Occup. Physiol. 1990, 61, 486-490. [CrossRef] [PubMed]

27. Stuessi, C.; Hofer, P.; Meier, C.; Boutellier, U. L -Carnitine and the recovery from exhaustive endurance exercise: A randomised, double-blind, placebo-controlled trial. Eur. J. Appl. Physiol. 2005, 95, 431-435. [CrossRef] [PubMed]

28. Orer, G.E.; Guzel, N.A. The Effects of Acute L-carnitine Supplementation on Endurance Performance of Athletes. J. Strength Cond. Res. 2014, 28, 514-519. [CrossRef]

29. Siliprandi, N.; Di Lisa, F.; Pieralisi, G.; Ripari, P.; Maccari, F.; Menabo, R.; Giamberardino, M.A.; Vecchiat, L. Metabolic changes induced by maximal exercise in human subjects following L-carnitine administration. Biochim. Biophys. Acta (BBA)-Gen. Subj. 1990, 1034, 17-21. [CrossRef]

30. Soop, M.; Björkman, O.; Cederblad, G.; Hagenfeldt, L.; Wahren, J. Influence of carnitine supplementation on muscle substrate and carnitine metabolism during exercise. J. Appl. Physiol. 1988, 64, 2394-2399. [CrossRef]

31. Wyss, V.; Ganzit, G.P.; Rienzi, A. Effects of L-carnitine administration on VO2max and the aerobic-anaerobic threshold in normoxia and acute hypoxia. Eur. J. Appl. Physiol. Occup. Physiol. 1990, 60, 1-6. [CrossRef] [PubMed]

32. Mor, A.; Baynaz, K.; Ipekoglu, G.; Arslanoglu, C.; Acar, K.; Cakir, H.I.; Arslanoglu, E. Effect of L-Carnitine Supplementation on Weight Loss and Body Composition of Taekwondo Players. J. Sports Educ. 2018, 1, 1-8. 
33. Cooper, M.B.; Jones, D.A.; Edwards, R.H.T.; Corbucci, C.; Montanari, G.; Trevisani, C. The effect of marathon running on carnitine metabolism and on some aspects of muscle mitochondrial activities and antioxidant mechanisms. J. Sports Sci. 1986, 4, 79-87. [CrossRef]

34. Müller, D.M.; Seim, H.; Kiess, W.; Ster, H.L.; Richter, T. Effects of oral L-carnitine supplementation on in vivo long-chain fatty acid oxidation in healthy adults. Metabolism 2002, 51, 1389-1391. [CrossRef]

35. Parandak, K.; Arazi, H.; Khoshkhahesh, F.; Nakhostin-Roohi, B. The Effect of Two-Week L-Carnitine Supplementation on Exercise -Induced Oxidative Stress and Muscle Damage. Asian J. Sports Med. 2014, 5, 123-128. [PubMed]

36. Giamberardino, M.A.; Dragani, L.; Valente, R.; Di Lisa, F.; Saggin, R.; Vecchiet, L. Effects of Prolonged L-Carnitine Administration on Delayed Muscle Pain and CK Release After Eccentric Effort. Endoscopy 1996, 17, 320-324. [CrossRef] [PubMed]

37. Arenas, J.; Huertas, R.; Campos, Y.; Díaz, A.E.; Villalón, J.M.; Vilas, E. Effects of L-carnitine on the pyruvate dehydrogenase complex and carnitine palmitoyl transferase activities in muscle of endurance athletes. FEBS Lett. 1994, 341, 91-93. [CrossRef]

38. Gorostiaga, E.; Maurer, C.; Eclache, J. Decrease in Respiratory Quotient During Exercise Following L-Carnitine Supplementation. Int. J. Sports Med. 1989, 10, 169-174. [CrossRef]

39. Huertas, R.; Campos, Y.; Díaz, E.; Esteban, J.; Vechietti, L.; Montanari, G.; D’Iddio, S.; Corsi, M.; Arenas, J. Respiratory chain enzymes in muscle of endurance athletes: Effect of L-carnitine. Biochem. Biophys. Res. Commun. 1992, 188, 102-107. [CrossRef]

40. Oyono-Enguelle, S.; Freund, H.; Ott, C.; Gartner, M.; Heitz, A.; Marbach, J.; Maccari, F.; Frey, A.; Bigot, H.; Bach, A.C. Prolonged submaximal exercise and L-carnitine in humans. Graefe's Arch. Clin. Exp. Ophthalmol. 1988, 58, 53-61. [CrossRef] [PubMed]

41. Swart, I.; Rossouw, J.; Loots, J.; Kruger, M. The effect of L-carnitine supplementation on plasma carnitine levels and various performance parameters of male marathon athletes. Nutr. Res. 1997, 17, 405-414. [CrossRef]

42. Badrasawi, M.; Shahar, S.; Zahara, A.M.; Nor Fadilah, R.; Singh, D.K. Efficacy of L-carnitine supplementation on frailty status and its biomarkers, nutritional status, and physical and cognitive function among prefrail older adults: A double-blind, randomized, placebo-controlled clinical trial. Clin. Interv. Aging 2016, 11, 1675-1686. [CrossRef] [PubMed]

43. Wächter, S.; Vogt, M.; Kreis, R.; Boesch, C.; Bigler, P.; Hoppeler, H.; Krähenbühl, S. Long-term administration of 1-carnitine to humans: Effect on skeletal muscle carnitine content and physical performance. Clin. Chim. Acta 2002, 318, 51-61. [CrossRef]

44. DrĂgan, I.G.; Vasiliu, A.; Georgescu, E.; Eremia, N. Studies concerning chronic and acute effects of L-carnitina in elite athletes. Physiologie 1989, 26, 111-129. [PubMed]

45. Natali, A.; Santoro, D.; Brandi, L.S.; Faraggiana, D.; Ciociaro, D.; Pecori, N.; Buzzigoli, G.; Ferrannini, E. Effects of acute hypercarnitinemia during increased fatty substrate oxidation in man. Metabolism 1993, 42, 594-600. [CrossRef]

46. Pistone, G.; Marino, A.; Leotta, C.; Dell'Arte, S.; Finocchiaro, G.; Malaguarnera, M. Levocarnitine administration in elderly subjects with rapid muscle fatigue: Effect on body composition, lipid profile and fatigue. Drugs Aging 2003, 20, 761-767. [CrossRef] [PubMed]

47. Nüesch, R.; Rossetto, M.; Martina, B. Plasma and urine carnitine concentrations in well-trained athletes at rest and after exercise. Influence of L-carnitine intake. Drugs Exp. Clin. Res. 1999, 25, 167-171.

48. Hiatt, W.R.; Regensteiner, J.G.; Wolfel, E.E.; Ruff, L.; Brass, E.P. Carnitine and acylcarnitine metabolism during exercise in humans. Dependence on skeletal muscle metabolic state. J. Clin. Investig. 1989, 84, 1167-1173. [CrossRef] [PubMed]

49. Harris, R.C.; Foster, C.V.; Hultman, E. Acetylcarnitine formation during intense muscular contraction in humans. J. Appl. Physiol. 1987, 63, 440-442. [CrossRef]

50. Carlin, J.I.; Reddan, W.G.; Sanjak, M.; Hodach, R. Carnitine metabolism during prolonged exercise and recovery in humans. J. Appl. Physiol. 1986, 61, 1275-1278. [CrossRef] [PubMed]

51. Janssen, G.M.E.; Scholte, H.R.; Vaandrager-Verduin, M.H.M.; Ross, J.D. Muscle Carnitine Level in Endurance Training and Running a Marathon. Int. J. Sports Med. 1989, 10, S153-S155. [CrossRef]

52. Arenas, J.; Ricoy, J.R.; Encinas, A.R.; Pola, P.; D'Iddio, S. Carnitine in muscle, serum, and urine of nonprofessional athletes: Effects of physical exercise, training, and L-carnitine administration. Muscle Nerve 1991, 14, 598-604. [CrossRef] [PubMed]

53. Drăgan, G.I.; Vasiliu, A.; Georgescu, E.; Dumas, I. Studies concerning chronic and acute effects of L-carnitine on some biological parameters in elite athletes. Physiologie 1987, 24, 23-28.

54. Drăgan, G.I.; Wagner, W.; Ploeşteanu, E. Studies concerning the ergogenic value of protein supply and 1-carnitine in elite junior cyclists. Physiologie 1988, 25, 129-132. [PubMed]

55. Geidl, W.; Wais, J.; Fangmann, C.; Demisse, E.; Pfeifer, K.; Sudeck, G. Physical activity promotion in daily exercise therapy: The perspectives of exercise therapists in German rehabilitation settings. BMC Sports Sci. Med. Rehabil. 2019, 11, 28. [CrossRef] [PubMed]

56. Constantin-Teodosiu, D.; Carlin, J.I.; Cederblad, G.; Harrist, R.C.; Hultman, E. Acetyl group accumulation and pyruvate dehydrogenase activity in human muscle during incremental exercise. Acta Physiol. Scand. 1991, 143, 367-372. [CrossRef]

57. Lennon, D.L.; Stratman, F.W.; Shrago, E.; Nagle, F.J.; Madden, M.; Hanson, P.; Carter, A.L. Effects of acute moderate-intensity exercise on carnitine metabolism in men and women. J. Appl. Physiol. 1983, 55, 489-495. [CrossRef] [PubMed]

58. Malaguarnera, G.; Catania, V.E.; Bonfiglio, C.; Bertino, G.; Vicari, E.; Malaguarnera, M. Carnitine Serum Levels in Frail Older Subjects. Nutrients 2020, 12, 3887. [CrossRef] [PubMed] 
59. Roepstorff, C.; Halberg, N.; Hillig, T.; Saha, A.K.; Ruderman, N.B.; Wojtaszewski, J.F.P.; Richter, E.A.; Kiens, B. Malonyl-CoA and carnitine in regulation of fat oxidation in human skeletal muscle during exercise. Am. J. Physiol. Metab. 2005, 288, E133-E142. [CrossRef] [PubMed]

60. Maughan, R.J. Nutritional ergogenic aids and exercise performance. Nutr. Res. Rev. 1999, 12, 255-280. [CrossRef] 